Tajana Pleše Petar Sekulić Boris Mostarčić
UDK: 904(497.5Rudina)

DOI: https://dx.doi.org/10.21857/9e31lhnrxm Izvorni znanstveni članak

Rukopis prihvaćen za tisak: 13.6.2018.

\title{
USUSRET ČETVRTOM DESETLJEĆU OD POČETKA ISTRAŽIVANJA BENEDIKTINSKE OPATIJE SV. MIHOVILA ARKANĐELA NA RUDINI
}

\author{
U zaledu mrki Psunj, mrk kao nigdje drugdje, a pred tobom puklo \\ ravno požeško polje sa bezbrojem sela i zaselaka. \\ Gj. Szabo, 1907.
}

\section{Sažetak}

Benediktinska opatija sv. Mihovila arkanđela na Rudini nalazi se na platou (419 mnv) vinorodnih obronaka Psunja, nedaleko od sela Čečavac, s kojega se pruža pogled na Požešku dolinu.

Opatija se prvi put spominje $u$ ispravi kralja Bele IV. iz 1250. godine, no pretpostavlja se da su je osnovali pripadnici roda Borić tijekom druge polovice 12. stoljeća, $u$ jeku romaničkog stilskog oblikovanja. Redovnici su je zauvijek napustili tijekom druge četvrtine 16. stoljeća, neposredno prije osnivanja Požeškog sandžaka.

Iako je rudinska opatija monumentalno ostvarenje romaničkog tipa u sjevernim krajevima Hrvatske (A. Mohorovičić), već ga više od stoljeća prati zla kob koja je počela ekstenzivnim odvozom kamene građe u vrijeme M. Rajnera. Naime, iako su istraživanja potrebna za dokumentiranje, proučavanje i razumijevanje svakog nalazišta, upravo se na rudinskom primjeru pokazalo istinitim načelo M. Wheelera, prema kojem je svako istraživanje uništavanje. Tome je pogodovalo nepostojanje jasnog koncepta obnove i prezentiranja te nedostatno i neadekvatno provedena zaštita.

Dva desetljeća nakon prestanka prvih radova na rudinskoj opatiji, zbog njezina alarmantnog stanja počelo se s revizijskim istraživanjima i izradom cjelovite nacrtne dokumentacije radi osmišljavanja sustavnih koraka potrebnih za konzerviranje i adekvatno prezentiranje toga iznimnog spomenika kasnosrednjovjekovne kulturne baštine.

Ključne riječi: Rudina; benediktinska opatija; konzerviranje; prezentiranje. 


\section{O povijesti rudinske opatije}

Benediktinska opatija sv. Mihovila arkanđela na Rudini nalazi se na vinorodnim obroncima Psunja, sjeverno od sela Čečavac (općina Brestovac, Požeško-slavonska županija). ${ }^{1}$ Smještena na platou (467 mnv) za koji se pretpostavlja da je bio omeđen jarkom sa sjeverne, istočne i jugoistočne strane, rudinska opatija svojim položajem dominira cijelom okolicom (Sekulić Gvozdanović, 2007: 40). Spomen na opatiju sačuvao se do danas u nazivu sela Opatovca i potoku Rudina, dok se naziv nekadašnjega naselja Benekovac može tumačiti kao odraz sjećanja na benediktince (Bösendorfer, 1910: 150; Ostojić, 1965: 51).

Rudinska opatija sv. Mihovila arkanđela na Rudini (Rodyna, Rudina, Rwdyna, Rudyna) tijekom kasnog srednjeg vijeka nalazila se na južnom obodu Pečujske biskupije, ${ }^{2}$ nedaleko od granice sa Zagrebačkom biskupijom, ujedno na granici srednjovjekovne Požeške i Križevačke županije (Bösendorfer, 1910: 150, 276; Andrić, 1998: 31-32). ${ }^{3}$

Rudina se prvi put u poznatim sačuvanim vrelima spominje $u$ darovnici kralja Andrije II. iz 1210. godine, no samo kao toponim (CD III, 97-99). S obzirom na tumačenja spomenute isprave, odnosno sugerira li isprava postojanje opatije već 1210 . godine, mišljenja se razilaze. Unatoč brojnim nepoznanicama, podatak da je do Rudine vodila cesta navela je A. Horvat ${ }^{4}$ na zaključak da se $\mathrm{u}$ ispravi spominje opatija sagrađena potkraj 12. stoljeća (A. Horvat, 1962: 15, 26). Da je spomenuta isprava potvrda postojanja opatije, smatra i S. Andrić, dok činjenicom da Rudina ne graniči $\mathrm{s}$ Račešom (omeđuje ga dio ceste koji vodi prema Rudini) opravdava izostanak bilo kakvog opisa opatije (Andrić, 1998: 34-35). Prvi poznati sačuvani nedvojbeni spomen opatije potječe iz isprave kralja Bele IV. od 5. srpnja 1250. godine (Andrić, 2003: 91; Andrić, 2005: 77-78; Rupert, 2013: 49).

Isprava o zamjeni posjeda, sastavljena 1279. godine pred kaptolom sv. Petra u Požegi, posebno je zanimljiva jer se u njoj spominje prvi poznati opat Juraj (Georgio abbate de Rodyna) i njezini patroni (patroni ecclesie de Rodyna) (CD VI, 321-322; Klaić, 1986: 49; Andrić, 1998: 35).

I tumačenja te isprave nisu jedinstvena. J. Adamček i N. Klaić smatraju da su osnivači opatije u Rudini bili pripadnici obitelji Borić - sam ban Borić ili njegov sin

\footnotetext{
Rudinska opatija pojedinačno je zaštićeno nepokretno kulturno dobro (Z-2314, Registar kulturnih dobara Ministarstva kulture) i nalazi se na k. č. 1344 (z. k. ul. 187) u k. o. Šnjegavić.

2 Više o prostornim odrednicama vidi: Kiss, 2009: 351-378.

3 Prema mišljenju I. Ostojića, prvi benediktinski cenobij na području Panonije bila je opatija sv. Martina u Pannonhalmi (de sacro Monte Pannoniae), osnovana potkraj 10. ili početkom 11. stoljeća (Ostojić 1965: 9-10). Nadalje, navodi da su se benediktinski samostani u Panonskoj Hrvatskoj formirali u dvije skupine: prva, brojnija, u Srijemu i druga oko Požege i u srednjem dijelu Slavonije (Ostojić, 1965: 11).

4 Široku dataciju A. Horvat kritizirala je N. Klaić (Klaić, 1986: 39-40).
} 
nepoznata imena (Adamček, 1977: 114; Klaić, 1986: 51). Svoju tvrdnju N. Klaić potkrijepila je činjenicama da je bosanski ban Borić bio vrlo ugledna osoba na dvoru kralja Stjepana III. (1163.-1164.), vjerojatno prvi požeški župan te vlasnik brojnih posjeda oko Požege, među kojima i orljavačkog vlastelinstva, na čijem se području nalazila opatija (Klaić, 1986: 53, 55). Nadalje, N. Klaić prihvatila mišljenje S. Pavičića da su sve osobe iz isprave 1279. godine bili patroni opatije u Rudini te spomenutu zamjenu posjeda tumači kao jasan znak patronatskog prava Borića (Klaić, 1986: 51, 55). S obzirom na povijesni kontekst, S. Andrić ne odbacuje moguću vezu Borića i Rudine, no spomenutu ispravu ${ }^{5}$ ne smatra njezinim dokazom (Andrić, 1998: 36). Iako odbacuje argumente N. Klaić, M. Karbić se također slaže s pretpostavkom da su osnivači rudinske opatije bili ban Borić ili njegovi potomci (Karbić, 2005a: 192). Svoju pretpostavku temelji na činjenici da se za sve rudinske patrone u 14. stoljeću može dokazati pripadnost rodu Borića te na temelju analize rasprostiranja posjeda Borićevih nasljednika (Karbić, 2005a: 192).

Sačuvana isprava iz 1349. godine o parnici između požeškog prepozita i kraljičina vicekancelara Andrije i četvorici braće roda Giletovih oko posjeda Koprivna i Selna izuzetno je vrijedno vrelo (Klaić, 1986: 44; Andrić, 1998: 37; Buturac, 2004: 183192). Naime, Andrija je kao patron opatije u Rudini (ecclesie seu monasteri de Rudyna) osporio ugovore o ustupanju posjeda između opata Nikole (abbas de Rudyna) iz 1333. godine te opata Petra (abbas ecclesie de Rudina) iz 1335. godine i Emerika Giletovog (Andrić, 1998: 37). Odlukom kraljevskog suda ugovor je poništen te su braća uz naknadu morala napustiti sporne posjede (Andrić, 1998: 38). Spomenuti spor N. Klaić tumači kao borbu nasljednika bana Borića za spomenute posjede uz pomoć požeškog kaptola, dok S. Andrić napominje da je riječ o zaštiti patronatskog prava, ${ }^{6}$ odnosno nadzoru raspolaganja posjedima darovanim opatiji (Klaić, 1986: 48).

5 S. Andrić ističe distinkciju između Grgura, Chelka, Borića III. i sinova Odolinih te trojice patrona opatije, koji čini se nisu pripadnici obitelji Borić (Andrić, 1998: 36). S druge strane, M. Karbić je odbacila takvo mišljenje uz napomenu da je na navedenom primjeru vidljiv princip rođačkog prava (Karbić, 2005a: 176). Da patroni nisu uvijek nastupali zaštitnički, svjedoči sačuvana tužba opata Stjepana iz 1380. godine iz koje su vidljivi primjeri ograničavanja prava raspolaganja posjedima nekim članovima roda Cerničkih i Podvrških (Andrić, 1998: 40; Karbić, 2005a: 193). Čini se kako je tijekom druge polovice 14. stoljeća došlo do diobe patronata nad Rudinom (Andrić, 1998: 41).

6 Za razliku od N. Klaić i M. Karbić, S. Andrić napominje da iz sačuvanih isprava nije moguće prepozita Andriju dovesti u vezu s potomcima bana Borića, niti je moguće zaključiti što se dogodilo s njegovim nasljednicima (Klaić, 1986: 48; Andrić, 1998: 39, Karbić 2013: 153). Iz isprava se također ne može zaključiti što se dogodilo s patronima potomcima utemeljitelja opatije, odnosno jesu li patronatsko pravo prodali ili zamijenili ili se skrivaju pod imenom nekog od navedenih rodova: Desislavići, tj. Cernići (de Cesrnek), Podvrški (de Poduers) i plemići od Godesne (de Godezna) (Andrić, 1998: 41; Grgin, 2012: 107-130). Naime, od prve polovice 14. do početka 15. stoljeća pojedinci se sve više označuju svojom pripadnošću određenoj grani obitelji te se nazivaju prema svojem glavnom posjedu (Grabarski, Podvrški, Cernički), a ne više kao pripadnici roda Borića (Karbić, 2005a: 195). Tako su pripadnici obitelji Dežević/ Desislavići (Dessewffy), koji su početkom 16. stoljeća preuzeli opatiju u Rudini, potomci jednog ogranka Cerničkih te tako i vjerojatni sljednici roda Borića (Karbić, 2005a: 77, 86; Karbić, 2005b: 58). 
Dvojica opata iz spomenute parnice pojavljuju se u još dva dokumenta. Ostao je sačuvan gotički opatski pečat s natpisom $+S$ (igillum) Fratris Nicolai abbatis d(e) Rudina (Andrić, 1998: 39). Opat Petar se pak spominje u računima izvanredne papinske desetine koja se u Ugarskoj skupljala od 1332. ${ }^{7}$ do 1337. godine (Andrić, 1998: 39). Rudinski opat platio ju je jedanput, 1335. godine, te se navodi kao Item dominus Petrus abbas de Rodyna solvit XXXVIII grossos (Kempf, 1907: 245; Andrić, 1998: 39; Buturac, 2004: 175). Iako se spomenuta uplata može smatrati jednom od većih unutar požeškog arhiđakonata, u širem je kontekstu ipak riječ o skromnom prilogu (Andrić, 1998: 39).

Rudinski opati sudjelovali su u službenim procedurama dodjeljivanja crkvenih položaja i prihoda $u$ požeškom arhiđakonatu ${ }^{8}$ te $u$ funkcioniranju benediktinske provincije (Andrić, 1998: 40). Tako se rudinski opat Nikola spominje u ispravi izdanoj 1366. godine ${ }^{9}$ za vrijeme provincijskog kapitula koji se održavao u Monyoródu (danas Mogyoród) u Peštanskoj županiji. Naime, nakon izvješća vizitatora o neregularnostima u samostanu Grab i njegovoj granđi, iskaz je zatražen od opata četiriju samostana najbližih spomenutim posjedima, među kojima je bio i rudinski (Andrić, 2005: 85).

U sačuvanoj ispravi iz 1395. godine spominje se pavlin Stjepan, koji je uz dopuštenje poglavara i kardinala prezbitera sv. Suzane prešao iz samostana Bonis u Pečuškoj biskupiji u opatiju u Rudini (Andrić, 1998: 41; Buturac, 2004: 235). Dopuštenje za ostanak u Rudini izdao mu je papa Bonifacije IX. 13. siječnja 1395. godine. ${ }^{10}$

Rudinska se opatija tijekom 15. stoljeća spominje u većem broju sačuvanih isprava, koje upućuju na zanimljivu ulogu njezinih opata u širem povijesno-političkom kontekstu.

Zbog ubojstva magistra Jakova i njegove žene, kralj Žigmund oduzeo je 1405. godine sve posjede literatu Pavlu, sinu Nikole Podvrškog i sinovima Dominika Orljavačkog te ih dodijelio erdeljskom vojvodi Ivanu Tamásyu (Andrić, 1998: 42). Među oduzetim posjedima spominje se i patronat nad rudinskom opatijom (necnon patronatu monasterii ecclesie beati Michaelis archangeli de Rudyna) (Buturac, 2004: 239-240).

Spor Tamásya i razgranatog roda Podvrških trajao je godinama, no kulminirao je 1419. godine neprijateljstvom u koje je upleten i opat Rudine (Andrić, 1998:

\footnotetext{
Rudina se od 1332. do 1372. godine navodi kao Rodyna mon u Vat. I/1, 315 (Heller, 1975: 182).

8 Neimenovani rudinski opat spominje se u tri navrata (1363., 1364. i 1366. godine) $\mathrm{u}$ registrima pape Urbana V. (1362.-1370.)

9 Rudina se od 1366. do 1380. godine navodi kao Rudina, Rwdyna u F. IX/5, 431 i u Cs. II, 424, a 1349. godine navodi se kao mon beati Michaelis archangeli de Rudyna u Cod. XI, 509 (Heller, 1975: 182).

10 Bula pape Bonifacija IX. otkrivena na Rudini 2003. godine, prema mišljenju V. Krambergera, može se dovesti u vezu sa spomenutim događajem (Kramberger, 2013: 110). Valja napomenuti da je to treća papinska bula pronađena na prostoru rudinske opatije. Druga bula pape Bonifacija IX. pronađena je 2003. godine (Tomičić, 2013: 44-45), dok je bula pape Eugenija IV. (1441.-1447.) pronađena izvan arheološkog konteksta na prostoru opatijske crkve (Margetić, Margetić 2005: 290-292).
} 
44). Prema sačuvanim ispravama, prilikom posredovanja u sporu između obitelji Tamásy i Stjepana, "navodnog“ opata Rudine (et quendam Stephanum monachum, assertum abbatem de Rwdina), na posjedu Selna došlo je do napada na Augustina de Bayda (familijara Ladislava Tamásya i kaštelana Podvrškog) te podmetanja požara (Andrić, 1998: 44). Za poticanje napada osumnjičeni su Dominik Podvrški i rudinski opat Stjepan, no na kraju su oslobođeni optužbi (Ostojić, 1965: 49; Andrić, 1998: 44; Buturac, 2004: 261-267). Na temelju niza isprava o sporovima Tamásya i Podvrških, S. Andrić uočio je otpor požeškog kaptola, plemstva i klera prema obitelji Tamásy (Andrić, 1998: 44-45).

Čini se da je otpor Tamásyma moguće uočiti i u izboru nasljednika rudinskog opata Ivana 1423. godine. Naime, na temelju dviju sačuvanih isprava papinske kurije vidljivo je da su kandidati za službu opata bili rudinski redovnik Stjepan Milonavić ${ }^{11}$ te Demetrije, prior benediktinskog samostana Sv. Spasitelja u Szekszárdu (Andrić, 1998: 45; Buturac, 2004: 269). S. Andrić naznačuje da je Demetrije mogao biti kandidat Tamásya jer se njegov samostan nalazio u županiji Tolna, baš kao i matično područje obitelji Tamásy (Andrić, 1998: 45).

Sačuvani dopisi Demetrija papi Martinu V. donose zanimljive podatke o prihodima rudinske opatije. Naime, u prvom dopisu Demetrije je naveo da godišnji prihodi opatije iznose do 100 zlatnih florena, dok u drugome spominje 70 florena (Andrić, 1998: 45; Buturac, 2004: 269). Iako spomenute podatke treba promatrati u kontekstu obveze servitium commune, ${ }^{12}$ vjerojatno ih je moguće smatrati relevantnim u pogledu skromnih prihoda ${ }^{13}$ rudinske opatije. Sudeći prema djelomično sačuvanoj kaptolskoj ispravi od 8. srpnja 1425. godine u kojoj se spominje opat Stjepan (abbate monasteri de Rwdyna), može se zaključiti da je na kraju potvrđen upravo Stjepan (Andrić, 1998: 46; Buturac, 2004: 270). Činjenicu da pritom nastupa kao predstavnik patrona Tamásya, $\mathrm{S}$. Andrić smatra dokazom rješavanja dotadašnjih sukoba (Andrić, 1998: 46).

U sačuvanom ugovoru o nasljeđivanju između obitelji Tamásy i Héderváry, koji je sačuvan u ispravi budimskog kaptola izdanoj 25 . siječnja 1443. godine ${ }^{14}$ među po-

11 Vjerojatno „navodni“ opat Rudine koji se spominje u ispravama iz 1419. godine (Andrić, 1998: 45).

12 Riječ je o pristojbi koju je novoimenovani opat bio dužan uplatiti Svetoj Stolici u zamjenu za bulu o imenovanju. Ako su prihodi bili veći od sto florena, pristojba je iznosila jednu trećinu godišnjih prihoda. S obzirom na to da se rudinska opatija ne spominje u knjigama uplata, može se pretpostaviti da je bila oslobođena spomenute obveze (Andrić, 1998: 46).

13 Prema mišljenju J. Buturca, opatijski posjed bio je smješten između orljavačkog vlastelinstva te malih posjeda na jugu i istoku, a obuhvaćao je i nekoliko manjih brdskih siromašnih sela. Stoga je I. Buturac zaključio da je opatija bila razmjerno mala i siromašna (Buturac, 2004: 32). Sačuvana vrela također upućuju na relativno malu gospodarsku moć opatije u 15. i 16. stoljeću. No spomenute podatke ipak treba razmatrati oprezno zbog činjenice da ni izbjegavanje podmirivanja financijskih obaveza nije bila rijetka pojava.

14 Rudina se 1443./1444. godine navodi kao Rudyna u Cs. II, 424 (Heller 1975: 182). 
sjedima Henrika Tamásya u Požeškoj županiji spominje se i patronat nad Rudinom (ius patronatus abbacie ecclesie de Rudina) (Andrić, 1998: 46-47).

Na temelju sačuvane molbe papi Nikoli V. pretpostavlja se da je rudinska opatija stradala u provali osmanlijskih postrojbi u požeški kraj 1450. godine. Tada su srušene ili oštećene zgrade, ali i uništene sve isprave o crkvenim povlasticama (Andrić, 1998: 47). Stoga je od pape zatražen oprost za sve koji pobožno posjete rudinsku crkvu i pomognu u popravku i obnovi njezinih građevina (Andrić, 1998: 47). Papa Nikola V. traženu je povlasticu odobrio (monasterium S. Michaelis de Rudina ordinis $S$. Benedicti Quinque ecclesiensis diecis) $\mathrm{u}$ trajanju od sedam godina i isto toliko četrdesetnica za dva blagdana, za Miholje i za dan posvećenja crkve (Andrić, 1998: 47; Buturac, 2004: 298; Lukinović, 2004: 181).

Iako se pretpostavka da je opatija utvrđena nakon prvog stradavanja 1450. godine može činiti logičnom, na temelju trenutačno raspoloživih podataka to nije moguće potvrditi. Ideju o utvrđenoj opatiji uveo je još Gj. Szabo (Szabo, 1909: 209) na temelju jedne sačuvane puškarnice.

U sačuvanoj ispravi o prodaji nekih posjeda u Vukovskoj i Požeškoj županiji mačvanskom banu Ivanu Korođskom 1455. godine, kao jedan od susjeda spominje se upravitelj opatije (dominus Nicolaus, gubernator abbacie de Rwdyna in eadem Rwdyna) (Buturac, 2004: 307). Kako je to jedini spomen upravitelja Nikole, nije jasno zašto je samostan, tj. opatija, ostao bez opata i kako je došlo do postavljanja upravitelja (Andrić, 1998: 48-49).

Niz vrijednih podataka pružaju nam sačuvane isprave o parnicama zbog uobičajenih nasilja između četvorice članova roda Cerničkih s jedne strane te voćinskog kaštelana Joba Gorjanskog i opata Martina (Andrić, 1998: 48). Rudinskog opata teretili su među ostalim i za isključivanje iz patronata nad opatijom koji im „po svakom pravu pripada" (Andrić, 1998: 48). Na temelju sačuvanih podataka nije moguće zaključiti je li riječ o opatu Martinu koji se spominje u ispravi iz 1444 . godine..$^{15}$ Ako je riječ o istoj osobi, prema S. Andriću postoji mogućnost da je zbog nepravilnosti u obavljanju opatske službe upravitelj iz 1455. godine bio privremena mjera (Andrić, 1998: 48).

S obzirom na to da se kao patroni opatije ponovno pojavljuju Cernički, S. Andrić pretpostavlja da su Cernički iskoristili prazninu nastalu između izumiranja obitelji Tamásy i realizacije nasljednog ugovora obitelji Héderváry (Andrić, 1998: 49). Naime, patronsko pravo obitelji Héderváry (ius patronatus abbacie ecclesie de Rudina/Rwdyna. iuris patronatus abbacie ecclesie de Rwdina in Posega) spominje se tek $\mathrm{u}$ ispravama iz 1491. i 1492. godine (Andrić, 1998: 49; Buturac, 2004: 344-345). Franjo

\footnotetext{
15 Opat Martin (dominus frater Martinus abbas de Rudina) spominje se među svjedocima u sporu između Ladislava Čeha Levanjskog i baranjske obitelji Peterdy oko posjeda Orljavac (Andrić, 1998: 47; Buturac, 2004: 281).
} 
Héderváry založio je 1500. godine za 20.000 zlatnih forinti svojem šurjaku Stjepanu Rozgonyu niz posjeda te patronat nad rudinskom opatijom (Andrić, 1998: 50; Buturac, 2004: 353-354).

Isprave sastavljene početkom 16. stoljeća jasno upućuju na sve lošiju opću situaciju rudinske opatije, uzročno povezanu s općim porastom nestabilnosti zbog sve osjetnije prijetnje od osmanlijskih postrojbi.

To je vidljivo iz sačuvanog pisma pape Julija II. iz 1504. godine kojim nalaže popunjavanje ispražnjenog mjesta nakon odlaska posljednjeg opata Tome $u$ benediktinski samostan Báta u Ugarskoj (Buturac, 2004: 354-356). Opatija u Rudini predana je na prijedlog patrona Héderváryja na upravu (kao komendu) svećeniku Stjepanu Mihovilovom de Gibolt (Andrić, 1998: 50). Iz isprave je vidljivo da nije bilo moguće pronaći redovnike koji bi htjeli boraviti u opatiji koja se nalazi in finibus Turcorum situatum (Buturac, 2004: 354). Stoga se čini razumljivim naputak prema kojem je bilo potrebno zaustaviti pad broja redovnika (Andrić, 1998: 50). Papa je pritom pozvao predijalce i kmetove rudinske gospoštije da se pokore rečenom administratoru Stjepanu (Buturac, 2004: 31). U ispravi je također evidentno da su godišnji prihodi opatije bili manji od pedeset zlatnih florena godišnje, čime opatija nije potpadala pod obvezu plaćanja servitiuma commune, no bila je dužna podmiriti druge obveze (annata) (Buturac, 2004: 355). Prema vatikanskim knjigama računa, 20. prosinca 1504. godine umjesto novopostavljenog upravitelja Rudine potreban iznos za imenovanje platio je Juraj Mađar (Georgius Hungarus) (Andrić, 1998: 50).

Zbog nepodmirivanja obveza, a na temelju ugovora iz 1500. godine, Rozgonyi su 1511. godine pred budimskim kaptolom zatražili zabranu prodaje, zaloga ili zamjene dobara rudinskom patronu Franji Héderváryju (Andrić, 1998: 51). Unatoč zabrani, Franjo Héderváry slobodno je raspolagao spomenutom imovinom pa je 16. lipnja 1514. godine požeški kaptol potvrdio ugovor o nasljeđivanju posjeda u Požeškoj županiji s potomkom Franjom Dessewffyjem Cerničkim (Buturac, 2004: 360-362). Među posjedima se spominje patronat Rudine i njezine pripadnosti (iure patronatus monasterii et abbacie ecclesie beati Michaelis archangeli, Rudina appellati ordinis sancti Benedicti, in possesione similter Rudina vocata) (Buturac, 2004: 361). ${ }^{16}$

Nakon smrti opata Stjepana, kralj Ludovik II., na prijedlog patrona Franje Héderváryja, 1523. godine imenovao je novim upraviteljem opatije Nikolu Dessewffyja (Andrić, 1998: 51). Nikola se pritom obvezao da će unutar godine dana stupiti u benediktinski red te se brinuti da u samostanu, tj. opatiji bude dovoljno braće za obavljanje uobičajene svete službe (Andrić, 1998: 52). U međuvremenu je mjesto opata uzurpirao svjetovni svećenik Nikola Vukodlačić (Wokodlachyz) te je Nikola

16 Rudina se 1511. navodi kao Rwdyna u Héderváry I, 520 (Heller, 1975: 182), a 1514. kao mon et abbatia eccl beati Michaelis de Rwdyna u MHH. I/36, 275 (Heller, 1975: 182). 
Dessewffy dužnost preuzeo tek nakon intervencije kralja Ludovika II. i dominikanca Rome Cajetana ili Gaetana, papinskog legata u Ugarskoj (Andrić, 1998: 52). Iz papinskog odobrenja saznajemo da mu je uprava predana na deset godina; za to vrijeme može postati opatom. Spominje se i da godišnji prihod nije veći od 80 zlatnih florena (Andrić, 1998: 53). Slijedom papinske bule, požeški kustos Ivan Kazkffy de Pawlowcz imenovao je Nikolu pravim i zakonitim opatom 18. listopada 1524. godine (Andrić, 1998: 53). Tijekom boravka u rudinskoj opatiji kustos se uvjerio da je Nikola dobro primljen i dobio obećanje predijalaca i službenika o vjernosti novom opatu (Andrić, 1998: 53). Tako je, stjecajem okolnosti posljednji rudinski opat ${ }^{17}$ postao potomak nekadašnjih patrona Cerničkih, odnosno Desislavića. ${ }^{18}$

Svoje posjede u Požeškoj županiji Franjo Héderváry prodao je za šest tisuća zlatnih florena 1525. godine Ivanu Dessewffyju. Uz grad i kaštel Požegu te kaštel Podvršje, sa svim pripadajućim dobrima, naveden je i patronat nad Rudinom (Andrić, 1998: 53).

O posljednjih deset godina opatije u Rudini, koja su obilježena sve učestalijim pustošenjima osmanlijskih postrojbi, ne postoje poznata sačuvana vrela te nije moguće utvrditi je li opatija bila napuštena u trenutku kad je područje Požeštine došlo pod vlast Osmanlija 1536. i 1537. godine (Mažuran, 1977: 165; Moačanin, 1997: 32; Andrić, 1998: 53; Buturac, 2004: 370). Prema dostupnim vrelima i nalazima, može se pretpostaviti da su redovnici napustili opatiju zbog opće nesigurnosti najkasnije tridesetih godina 16. stoljeća.

Osnutkom Požeškog sandžaka 1538. godine (Moačanin, 1984: 107-118; Mujadžević, 2009: 89; Ural, 2011: 61-78) počela je uspostava i stabilizacija osmanlijske vlasti koja je trajala do 1691. godine (Mažuran, 1977: 165). U poznatim sačuvanim vreli$\mathrm{ma}^{19}$ iz razdoblja osmanlijske vladavine Rudina se spominje $u$ više navrata (u defterima sandžaka Požega od 1545., 1561. i 1579. godine), i to kao tvrđava. Rudina se prvi put $\mathrm{u}$ trenutačno poznatim osmanskim vrelima kao pusto selo spominje 1540. godine u popisu nahije Granica Požeškog sandžaka (Moačanin, 1997: 148). No već u idućem popisu iz 1545. godine navedeno je osam mezri koje su pripadale tvrđavi Rudine. Svi navedeni posjedi, u popisu navedeni kao zapušteni i bez posjednika, ustupljeni su na uživanje Murat-agi uz naknadu od sto akči tapijske pristojbe po mezri (Moačanin, 1997: 205, 209-210). U popisu iz 1561. godine kao posjed tvrđave Rudina navodi se devet mezri (Moačanin, 1997: 337-338, 344-345).

17 Ovdje valja navesti popis svih (do sada) poznatih rudinskih opata i upravitelja: Juraj (1279.), Nikola (1333.), Petar (1335.), Herman (1348.), Stjepan (1349.), Nikola (1366.), Stjepan/Demetrije (1419.), Martin (1444.), Nikola (upravitelj) (1455.), Martin (1464.), Toma (1492.), Stjepan de Gibolt (1504.) i Nikola Dessewfy / Nikola Vukodlački (1523.).

18 Prema mišljenju većine autora, obitelj Cerničkih (poslije Deževića, tj. Dessewffyja) loza je plemićke obitelji Borića (Karbić, 2005: 58).

19 Više o osmanskim arhivskim izvorima za povijest Slavonije i Srijema vidi: Mujadžević, 2010: 131-142. 
Stabilizacija i poboljšanje sigurnosne situacije (kao posljedica pomicanja ratnih djelovanja prema zapadu) odrazili su se pozitivno na gospodarstvo, što je dovelo do kolonizacije sela te općeg gospodarskog oporavka. Spomenuti trend uočljiv je u smanjenju broja mezri između popisa 1545. i 1561. godine, koje ponovno postaju gospodarski aktivna sela (Moačanin, 1997: 54). ${ }^{20}$ U popisu sandžaka Požega iz 1579. godine samo se mezra Petrovac navodi kao „, u blizini tvrđave Rudina“, dok se mezra Pridvrški navodi kao „blizu Rudina“ (Moačanin, 1997: 453, 492; Sršan et al., 2001: 68).

S obzirom na činjenicu da se u poreznim popisima spominju neke utvrde (Rudine, Vrhovci, Brestovac, Mitrovica) za čiju upotrebu ne nalazimo potvrde u poznatim osmanskim vrelima, pretpostavka N. Moačanina o privremenom korištenju Rudine čini se mogućom. Prema mišljenju N. Moačanina, spomenute su utvrde, ako su i bile $\mathrm{u}$ funkciji, bile korištene povremeno i ovisno o lokalnim prilikama, npr. kao uporište lokalnog muslimanskog stanovništva, povremenih posada ili poluvojnih organizacija (Moačanin, 1997: 87). Ako uzmemo u obzir opći porast nesigurnosti na području Požeškog sandžaka nakon osmanlijskog poraza u bitci kod Siska 1593. godine, spomenuta se pretpostavka čini prihvatljivom.

Kao što možemo vidjeti, Rudina se u većini slučajeva navodi kao tvrđava, odnosno utvrda, baš kao i u prvom spomenu nakon protjerivanja Osmanlija 1702. godine.

Valja napomenuti kako za sada nije moguće sa sigurnošću potvrditi nalaz ni jednog osmanlijskog nalaza na Rudini. U literaturi se spominju nadgrobni spomenici (nišani) te jedan (danas izgubljeni) natpis (Szabo, 1909: 209; Sokač Štimac, 1997: 22; Sokač Štimac, 2013: 22), pronađeni na Rudini. No nišani su pronađeni u Kujniku, dok točno mjesto nalaza nije poznato. Stoga do daljnjega neće biti moguće potvrditi jesu li se osmanlijske postrojbe koristile Rudinom kao vojnim uporištem ili se pojam utvrde sačuvao $u$ pisanim vrelima samo na temelju vidljive ruševine postojećeg objekta.

Iako opatija nije obnovljena nakon protjerivanja osmanlijskih snaga, uspomena na nju očuvala se u Zagrebačkoj nadbiskupiji u pridjevku Abbas S. Michaelis Archangeli de Rudina, koji je prvi nosio zagrebački kanonik Grgur Šubarić (1695.-1709.) (Kempf, 1906-1907: 245). Posljednji je tu titulu nosio požeški župnik Ivan Thaller, nakon čije se smrti 1876. godine titula više nije dodjeljivala pa se ta opatija ne spominje više ni među vakantima (Kempf, 1906-1907: 245). Uspomena na opatiju očuvala se i u matičnom pečuškom kaptolu, gdje je sačuvana titularna opatija sv. Mihaela de Rudine (Ostojić, 1965: 51). Za razliku od spomenute tradicije, ruševine opatije u Rudini izgubile su identitet pa se u zapisima iz 18. stoljeća spominje samo kao "tvrđava" Rudnik ili Rudin ${ }^{21}$ (Andrić, 1998: 54).

20 Zanimljivo je da je Ivan Dessewffy u svojoj oporuci sastavljenoj 1567. godine zamolio kralja Maksimilijana da njegove posjede Cernik, Rudinu i Brestovac u Požeškoj županiji, uspije li ih se osloboditi od Osmanlija, preda njegovim sestrama i unucima (Andrić, 1998: 53-54).

21 U popisu kotara Brestovac iz 1702. godine (komorskog provizora Gabrijela Hapsza), u odjeljku o selu Čečavac, koje u svojem djelu Dvjestogodišnjica oslobođenja Slavonije iz 1891. godine donosi T. Smičiklas, 


\section{O prvim stručnim i znanstvenim spomenima rudinske opatije}

Rudinsku opatiju sv. Mihovila arkanđela tadašnjoj je javnosti prvi predstavio Gj. Szabo nakon što ju je posjetio 1906. godine. Zabilježio je položaj: „nad bijednim selom Čečavcem još su danas ostanci tamo, gdje vojnička karta bilježi ‘Grad'“ (Szabo, 1907: 208) te opisao stanje: „Bijedni ostanci još štošta kazuju. Samostan je bio utvrđen poput onoga u Bijeloj, utvrde su okrenute bile prema Požegi, duboki šanac postoji tu i dan-danas. Među kamenjem ima dosta takova u kojima su urezane puškarnice. Zato veli i tu popis od g. 1702.: Ubi arx Rudnich vocata deserta et diruta in monticulo sita est. Građena je opatija u gotskom slogu, lijepo tesano kamenje i vješto izgrađeni ornamenti, pa napisi gotičkim pismenima: +HIC IACET TOLIZE... na drugom ... STEPH... potvrđuju to nepobitno. Među ovim ističe se osobito lijepo izrađen križ i ornament poput vrpce. Krasno sačuvane boje na fragmentima slikarija već su spomenute. Turski napis daje naslućivati, što se je i s ovom građevinom dogodilo." (Szabo, 1907: 209) Slika 1

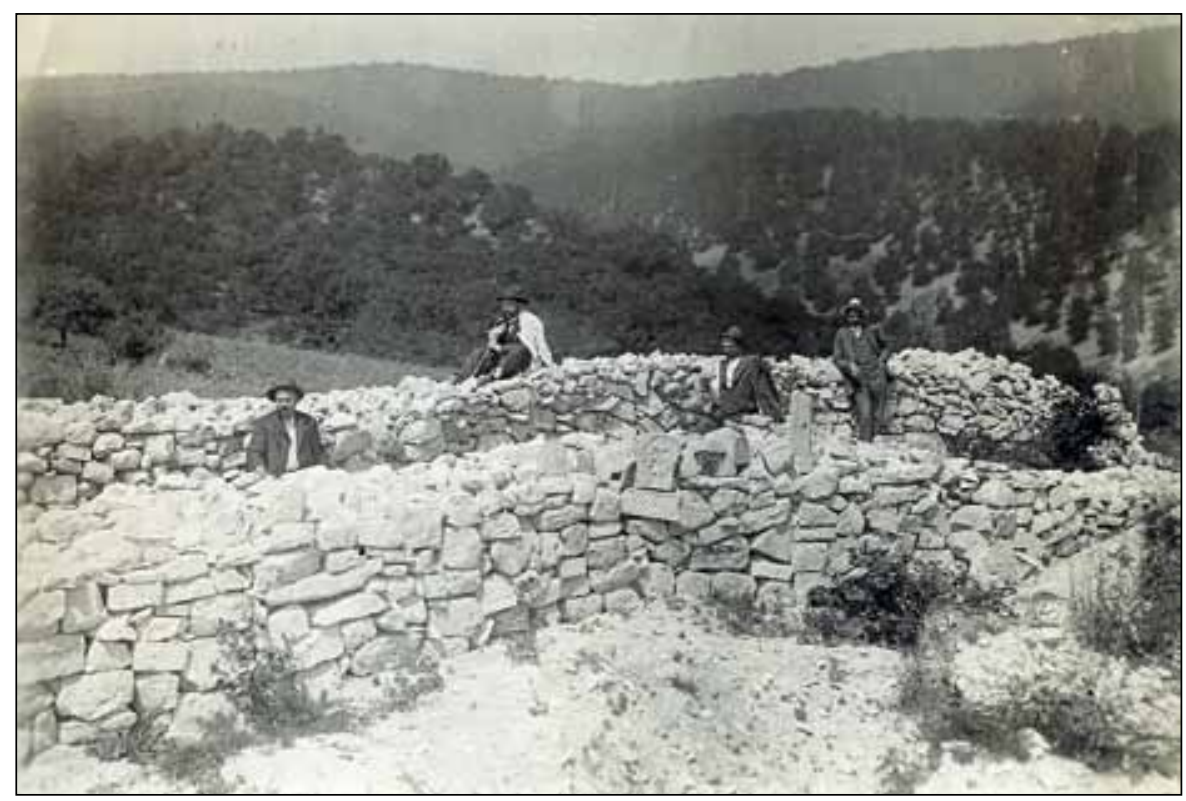

Slika 1. Opatija sv. Mihovila arkanđela na Rudini početkom 20. stoljeća. Snimka: J. Kempf, 1906. (fototeka Ministarstva kulture RH, inv. br.: 59209; neg.: /)

navodi se: ubi arx Rudinich vocata deserta et diruta in monticulo sita est. Ecclesia tamen nulla. (Kempf, 1906/1907: 245). S. Andrić donosi bilješku iz 1746. godine koja možda objašnjava gotovo potpun nestanak rudinskih ruševina: In pago Cseczavacz ad dominum Trenkianum Bresztovac spectante, cogitat episcopus Pakraczensis supra dictum pagum arcem Rudin diruere et ex ilis lapidibus novam aedificare ecclesiam... (Andrić, 1998: 54). 
Navedeni opis Gj. Szabe znatno je utjecao na daljnje zaključke o rudinskoj opatiji. To se poglavito odnosi na "duboki šanac postoji tu i dan-danas" te na "urezane puškarnice“, zbog čega je u literaturi prihvaćeno da je samostanski sklop (ti. opatija) bio utvrđen. Nažalost, nije sačuvana ni jedna fotografija šireg prostora rudinske opatije iz prve polovice 20. stoljeća pa taj podatak nije moguće provjeriti. Od spomenutih je puškarnica samo jedna ostala sačuvana in situ, što nije dovoljna potvrda zaključka da je opatija bila utvrđena.

Nadalje, Gj. Szabo je osim spomenute puškarnice skicirao i tri arhitektonske profilacije te tri natpisa. Jedan od natpisa je navedeni +HIC IACET TOLIZE..., drugi je također natpis na latinici, no nikako se ne može pročitati kao ....STEPH... kako ga navodi Gj. Szabo, dok je treći natpis onaj s arapskim pismom. ${ }^{22}$ Može se samo pretpostaviti da je Gj. Szabo znao što na natpisu piše jer navodi da "turski napis daje naslućivati, što se je i s ovom građevinom dogodilo“. Taj natpis ni do danas nije preveden.

Gj. Szabo je zapisao i kazivanje lokalnog življa o pronađenim detaljima. „Nedavno su otkopavali propale zidove, pa buduć da im treba kamena za gradnju crkve u Čečavcu, razlupaše stijene, koje su bile sve pokrivene slikama. A boje su tih slika tako jasne i svjetle, da se i nehote sjeti riječi Pillera i Mitterpachera. Bili su prikazani ljudi na sredovječno odjeveni, jedan je pružao malu crkvicu... Sad je to sve sretno slupano!“ (Szabo, 1907: 208).

Iste je godine (1906.) Rudinu posjetio J. Kempf te je zamijetio da su brojne kuće u okolnim selima građene kamenom građom s Rudine (Kempf, 1906-1907: 245). Svakako najzanimljiviji podatak koji J. Kempf navodi jest onaj da je posljednjih godina 19. stoljeća brestovački vlastelin dr. Mijo Rajner dao kopati kamen za građu, prilikom čega su pronađene manje zidane prostorije oslikane freskama (Kempf, 19061907: 245-246).

Posebno je vrijedna fotografija koju je tijekom svojega posjeta 1906. godine snimio J. Kempf jer je to prva sačuvana fotografija stanja rudinske opatije. Na njoj je jasno vidljiva velika količina kamene građe pripremljene za daljnji transport, pri čemu su jasno uočljive (barem) četiri arhitektonske profilacije.

Iako vrlo šturo, stanje rudinske opatije naveo je i J. Bösendorfer (Bösendorfer, 1910: 150). Istraživanju povijesti rudinske opatije znatno je pridonio i povjesničar J. Ćuk (Ćuk, 1925, 85-101).

22 Skicu nalaza s Rudine Gj. Szabe te fotografije J. Kempfa i N. Vranića dobivene su na uvid ljubaznošću mr. sc. Sanje Grković (Fototeka Ministarstva kulture RH), na čemu joj ovom prilikom srdačno zahvaljujemo. 
Prema navedenom je razvidno da je rudinska opatija bila poznata među lokalnim stanovništvom kao zamjenski kamenolom. No prošlo je gotovo pola stoljeća od upozorenja Gj. Szabe o devastaciji toga objekta do prvog službenog proglasa o njegovoj zaštiti. Tek je na osnovi dopisa s detaljnim opisom onoga što su seljaci pronašli na brdu blizu Čečavca, koji je 1955. godine upravitelj Muzeja Požeške kotline Josip Langhamer uputio Povijesnom muzeju Hrvatske, zabranjeno svako daljnje kopanje na području rudinske opatije (Geber, 1979: 107-108). Nakon zaprimanja njegova dopisa, skupina stručnjaka obišla je Rudinu te okolna sela Čečavac, Vučjak Čečavački, Jeminovac, Rasnu, Koprivnu, Šnjegavić, Kujnik, Džigerovce i Kamenski Vučjak. Ustanovljeno je da je i unatoč zabrani nastavljeno s odnošenjem kamena s Rudine, što je zabilježeno u izvještaju s obilaska terena iz 1957. godine.

Sljedećih je nekoliko godina darovnicama i otkupima pribavljena veća količina arhitektonske plastike, mahom ugrađene $\mathrm{u}$ objekte $\mathrm{u}$ navedenim selima, koji su svi bili trajno pohranjeni u Muzeju Požeške kotline. Prema E. Geber, posljednja (tj. posljednja prije početka sustavnih istraživanja) rudinska arhitektonska profilacija u Muzej je stigla 1977. godine (Geber, 1979: 110).

Nakon prikupljanja opisanih nalaza počelo je sustavnije upoznavanje šire javnosti s rudinskom opatijom, i to člancima J. Langhamera i M. Peića u dnevnom tisku ${ }^{23}$ (Horvat, 1962: 11). Uslijedio je važan rad o opatiji u Rudini A. Mohorovičića, u kojem je istaknuo njezinu iznimnu vrijednost, kao rijedak trag romaničke arhitekture na području kontinentalne Hrvatske (Mohorovičić, 1960: 430-431). Prvu veliku povijesno-umjetničku analizu prikupljenih arhitektonskih profilacija napisala je A. Horvat (Horvat, 1962: 11-28), dok je dragocjenu katalogizaciju predmetnih profilacija sastavila E. Geber (Geber, 1979: 105-129). Svakako treba spomenuti i rad N. Klaić (Klaić, 1986: 33-59) koji je, iako napisan nakon početka sustavnih arheoloških istraživanja, bio poticaj S. Andriću i M. Karbić da se prihvate detaljnih povijesnih istraživanja rudinske opatije.

Unatoč brojnim radovima koji su uslijedili nakon spomenutih objava J. Langhamera, opatija u Rudini ostala je vrlo skromno zabilježena na fotografijama. Stoga su dragocjene fotografije $\mathrm{N}$. Vranića snimljene 1959. godine (tj. prije početka sustavnih arheoloških istraživanja) kao orijentir o njezinu stanju sredinom minulog stoljeća.

${ }_{23}$ J. Langhamer, Ruševine „Gradovi“ kod Čečavca naš važni kulturno-historijski spomenik srednjeg vijeka, Požeški list, 23. 8. 1956.; M. Peić, Umjetnost u kamenolomu, Vjesnik, Zagreb, 7. 11. 1956. (Horvat, 1962: 11). 


\section{O arheološkim istraživanjima rudinske opatije od 1980. do 2003. godine}

Sustavna arheološka istraživanja trajala su šest sezona (1980., od 1986. do 1989. te 2000. godine). Vodila ih je D. Sokač Štimac (Gradski muzej Požega; dalje u tekstu: GMP). ${ }^{24}$ Tijekom tih nekoliko sezona istraživanja rudinska je opatija parcijalno istražena. ${ }^{25}$ Poslije dovršetka kasnijih sezona radova, istražena je arhitektura bila zaštićena privremenim metodama: u prvim sezonama nadstrešnicama, a u kasnijim geotekstilom. Nije poznato kada su temelji i zidovi opatijske crkve bili prekriveni cementnim mortom. Te metode konzerviranja (u najširem mogućem smislu), možda odabrane kao privremeno rješenje, uništile su veći dio istražene zidne mase, nepovratno onemogućujući interpretiranje njezina većeg dijela te su u konačnici prouzročile znatnu materijalnu štetu. (Pleše i Sekulić, 2014: 23-72).

Arheološka istraživanja rudinske opatije nastavljena su 2002. godine (Institut za arheologiju, Zagreb; dalje $\mathrm{u}$ tekstu: IARH) ${ }^{26} \mathrm{kad}$ je djelomično istraženo zapadno pročelje opatijske crkve (Tomičić et al., 2002). Vrlo su važne fotografije snimljene te sezone jer je njima zabilježeno stanje predvorja opatijske crkve prije znatne devastacije koja se dogodila u sljedećih deset godina.

Posljednja arheološka istraživanja provedena su 2003. godine (IARH), a tijekom tih radova istražen je prezbiterij i dio istočnog broda opatijske crkve. I u vrijeme tih istraživanja ustanovljeni su problemi $u$ interpretiranju, proizišli iz konzerviranja cementnim mortom (Tomičić et al., 2003).

Izuzev arhitekture o kojoj će biti riječi poslije, tijekom arheoloških istraživanja GMP-a pronađena je veća količina pokretnih arheoloških nalaza koje je D. Sokač Štimac u nekim radovima datirala od 9. do 15. stoljeća, a u nekima u vrijeme od 12. do 15. stoljeća. Osim radova T. Sekelj Ivančan (Sekelj Ivančan, 1997: 161-171), D. Margetića i D. Margetića (Margetić i Margetić, 2005: 290-292), Ž. Tomičića (Tomičić, 2010: 489-501; Tomičić 2013: 27-61), M. Pavličić (Pavličić, 2012: 231-246), M. Matije-

24 Dokumentacija (terenskih dnevnika, preliminarnih izvještaja i fotografija) vođena tijekom arheoloških istraživanja na Rudini nalazi se u GMP-u. Zahvalnost za omogućeni uvid u tu dokumentaciju dugujemo kolegicama Mirjani Šperandi i Mireli Pavličić Hein.

Treba navesti da su istraživanja bila vođena mimo standardizirane metodologije, uz izostanak adekvatne terenske, nacrtne i fotografske dokumentacije (čak i bez dokumentiranja pojedinih cjelina prije njihova uklanjanja, što je dovelo do nepovratnog gubitka podataka). Nadalje, dnevnik istraživanja vođen je vrlo šturo. Osim navedenog, velik problem u ispravnom interpretiranju istraženih nalaza (i arhitekture i pokretnih arheoloških nalaza) bila je nedosljednost u korištenju terminologije, ali i neobrađenost pronađenih nalaza, izostanak kataloga nalaza te izostanak prihvaćenih standarda pri istraživanju grobova. Nedostaju i podaci o tome gdje su odvezene iskopana zemlja i šuta te gdje je bio odložen kamen iz urušene zidne mase.

25 Opći geodetski situacijski plan (1:150) istraženog dijela rudinske opatije izrađen je tek 2001. godine (Kučinić d.o.o.). Do tada je bio korišten nekotirani nacrt T. Papića (s.a.; pismohrana GMP-a).

26 Zahvaljujemo ravnatelju Instituta za arheologiju dr. sc. Marku Dizdaru na ustupljenoj dokumentaciji iz obiju sezona arheoloških istraživanja. 
vić (Matijević, 2013: 61-86) i V. Krambergera (Kramberger, 2013: 103-113), do danas pronađeni nalazi nisu sustavno obrađeni (Pleše i Sekulić 2014: 46-50).

Rudinski je arhitektonski figuralni dekor najbogatija skupina romaničke plastike kontinentalne Hrvatske. Zahvaljujući radu E. Geber, popisani su svi ulomci i segmenti rudinskih arhitektonskih profilacija koje su prikupljene na inicijativu J. Langhamera do 1977. godine u okolnim selima (Geber, 1979: 105-129). Nalazi pronađeni tijekom arheoloških istraživanja koja je provela D. Sokač Štimac katalogizirani su znatno kasnije od pronalaska pa su zato i podaci koji prate „Zbirku srednjovjekovne kamene plastike i dijelova arhitekture s lokaliteta Rudina" unesenu u program M++ manjkavi (Pleše i Sekulić, 2014: 51-64).

Osim srednjovjekovnih nalaza, tijekom istraživanja pronađena je i manja količina prapovijesnih i rimskih nalaza (Pleše i Sekulić, 2014: 65). Unatoč njihovoj izvankontekstualnosti, moguće je zaključiti postojanje dugog kontinuiteta života na prostoru rudinske opatije - od prapovijesnog gradinskog naselja te rimskog nalazišta naseobinskog karaktera (Tomičić et al., 2002: 6).

\section{O revizijskim istraživanjima rudinske opatije}

Nakon dovršetka arheoloških istraživanja 2003. godine, taj je iznimno važan nepokretni spomenik kasnosrednjovjekovne slavonske kulturne baštine ostao prepušten neumitnom djelovanju vremena.

Zbog pogubnog djelovanja atmosferskih prilika na navedenom metodom zaštićene zidove, došlo je do njihove snažne dilapidacije, a cijeli je prostor opatije zarastao u gustu vegetaciju. Stoga je 2013. godine odlučeno da će se početi s iscrpnim revizijskim istraživanjima, čiji će rezultati poslužiti za izradu cjelovite nacrtne dokumentacije sa smjernicama za daljnje upravljanje tim objektom.

Predmetne godine istraženi je dio opatije u cijelosti očišćen od vegetacije, a sav je građevinski materijal prikupljen na južnom i istočnom slobodnom prostoru uz predmetni objekt. ${ }^{27} \mathrm{Kad}$ su dovršeni predmetni radovi, istraženi dio opatije temeljito je dokumentiran fotografiranjem i laserskim 3D skeniranjem (Vektra d.o.o.), a prema tako prikupljenima podacima izrađena je nacrtna dokumentacija s pripadajućim tehničkim opisom (Pleše i Sekulić, 2014). Slika 2

27 Radove od 2013. godine vodi Hrvatski restauratorski zavod. 


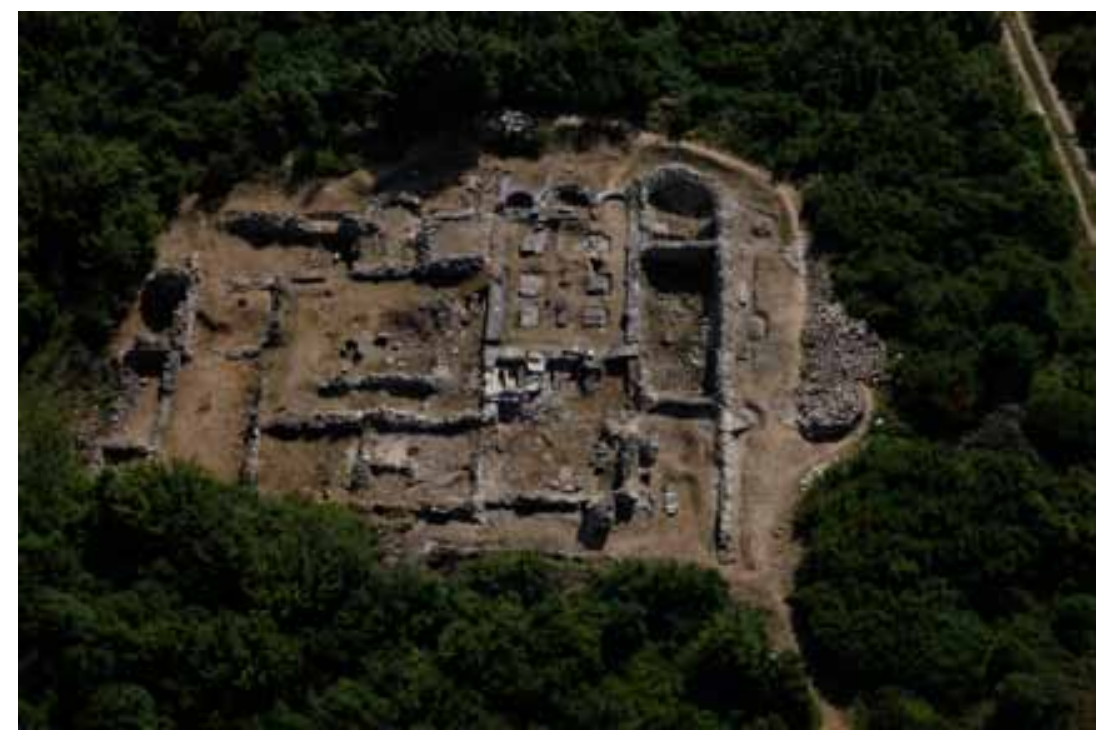

Slika 2. Pogled iz zraka na rudinsku opatiju sv. Mihovila arkanđela 2013. godine. Snimka: J. Kliska, 2013. (arhiva HRZ-a)

Nakon što je ustanovljeno stanje rudinske opatije, zaključeno je da će se sva buduća revizijska istraživanja provoditi isključivo ako je moguće osigurati subsekventno konzerviranje.

Cjelovita revizijska arheološka istraživanja crkve benediktinske opatije sv. Mihovila arkanđela na Rudini provedena su 2014. godine. Cilj tih radova bio je cjelovito istraživanje interijera toga sakralnog objekta (zidova i temelja, ali i grobova) s usporednom antropološkom analizom osteoloških nalaza in situ. Poslije dovršetka radova dopunjena je nacrtna dokumentacija (Pleše i Sekulić, 2015). Slika 3

Tijekom revizijskih radova u unutrašnjosti rudinske crkve 2014. godine, istraženo je 35 intaktnih kosturnih ukopa: četiri su bila ukopana u jednu zidanu grobnicu, ${ }^{28}$ njih 19 u 16 grobnica/raka ukopanih u nekompaktni kameni živac, ${ }^{29}$ a preostali izravno u zemljani naboj bez grobne strukture. Slika 4

28 Jedine tri zidane grobnice u rudinskoj crkvi bile su sagrađene od opeka kasnosrednjovjekovnog formata te spolija (rimskih tegula i klesanaca). Nije moguće zaključiti jesu li rimski elementi bili korišteni zbog nedostatka drugog građevnog materijala ili su pak bili namjerno korišteni kao dekorativni element. Prva je smještena između zapadnog pročelja i zapadnog profila prve baze $u$ južnom redu stupova/stubova, druga između srednje i istočne baze u sjevernom redu stupova/stubova, a treća između srednje i istočne baze južnog reda stupova/stubova.

29 Grobnice/rake su logična posljedica praktičnog ukopavanja u opatijsku crkvu zbog geomorfoloških karakteristika terena. Razmještaj pokojnika unutar grobnica/raka ukopanih u nekompaktni kameni živac jasno upućuje na kontinuitet korištenja jednog grobnog mjesta. 


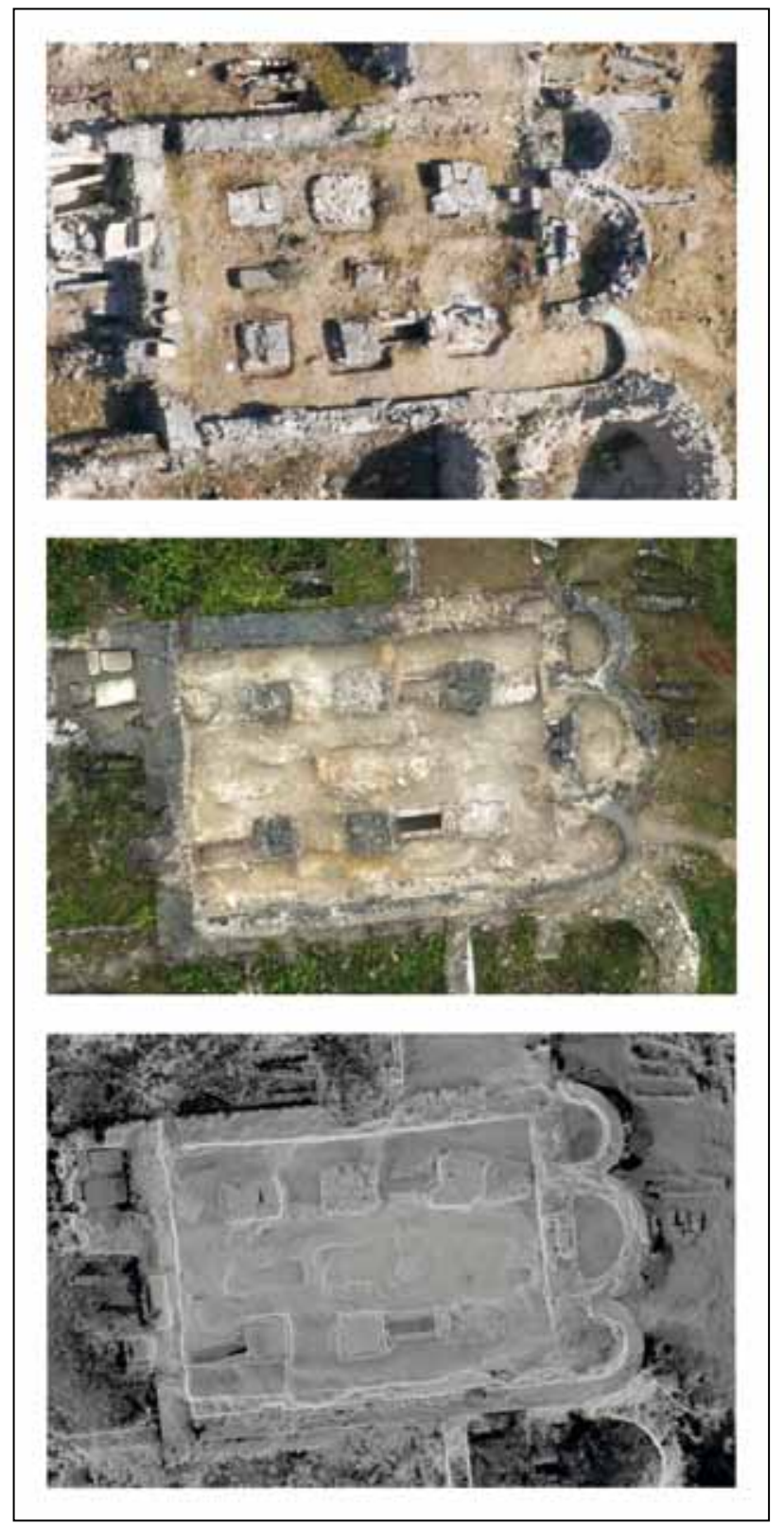

Slika 3. Pogled iz zraka na rudinsku opatijsku crkvu prije i nakon revizijskih istraživanja. Snimke: J. Kliska, 2013. i Lupercal M.T. j.d.o.o., 2014.. Izrada: Vektra d.o.o., 2014. (arhiva HRZ-a) 


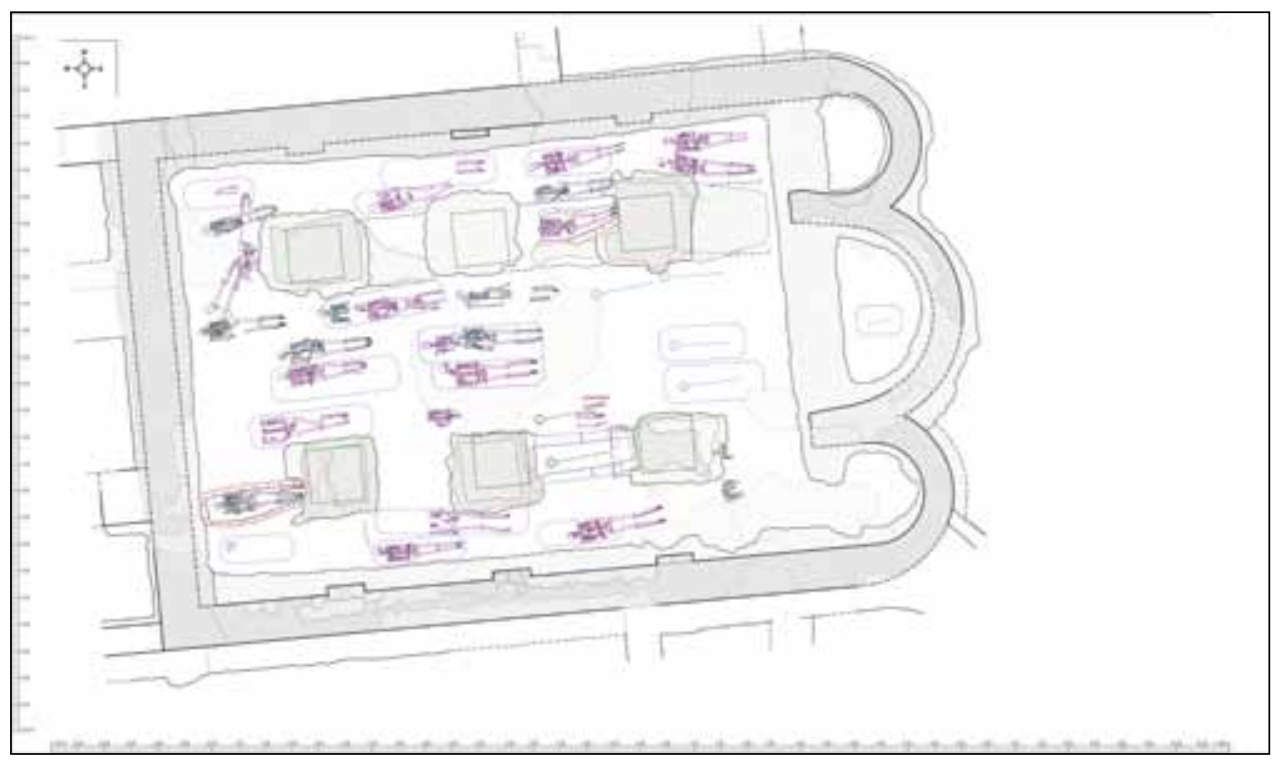

Slika 4. Tlocrt rudinske opatijske crkve s označenim svim istraženim (i evidentiranim) grobovima. Izrada: T. Pleše, 2014. (arhiva HRZ-a)

Broju istraženih grobova 2014. godine valja dodati i one pronađene $u$ istraživanju 1987. te možda 1988. godine (GMP) $)^{30}$ te šest istraženih 2003. godine (IARH). ${ }^{31}$

Ukupan broj istraženih (i evidentiranih) grobova u unutarnjem prostoru opatijske crkve iznosi 43 (tj. 45). Od toga je broja bilo moguće odrediti spol i starost za 41 pokojnika (ukupno 24 osobe muškog spola, devet osoba ženskog spola te osam subadulta $^{32}$ ). Tome broju dodaju se i (minimalno) 54 pokojnika (11 subadulta te 43

30 Kao što je navedeno, istraženi su grobovi jedan od najvećih problema uočenih $u$ dokumentiranju vođenja navedenih istraživanja. Naime, jedini orijentir za određivanje pozicije istraženih grobova jest shematski tlocrt na kojem se nalazi nadnevak iz 2000. godine. No na tom su shematskom tlocrtu jednakim oznakama $(G)$ označeni i grobovi ukopani u zemlji i zidane grobnice. Ponajveći je problem što u shematski tlocrt nisu ucrtani svi istraženi grobovi, a nisu označene ni grobnice koje se paušalno spominju u dnevniku radova i pripadajućem izvještaju. Nadalje, na shematskom je tlocrtu uočeno i označavanje grobova, tj. grobnica istim brojevima, a razdvojeni su isključivo bojama. Ujedno ne postoje (ili nisu vođeni) grobni zapisnici, a istraženi grobovi, tj. grobnice, nisu dosljedno fotografirani. Poseban je problem to što ni u dnevniku ni u izvještaju nije navedeno u kojim su grobovima pronađeni nalazi. (Sokač Štimac, 1987a: 1-6; Sokač Štimac, 1987b: 1-7)

31 U središnjoj apsidi pronađen je jedan subadult, a pet grobova odraslih osoba pronađeno je na prostoru lađe ispred središnje apside. Prema nalazima je Ž. Tomičić pretpostavio da su pokojnici bili pripadnici visokog društva, možda čak i plemićkih obitelji (Tomičić et al., 2003: 5-7; Tomičić, 2013: 39-45).

32 Bez obzira na dubinu ukopa, zanimljiv je velik broj ukopa subadulta te njihov položaj. Za tri groba subadulta zbog položaja unutar crkve možemo pretpostaviti da su bili ukopani nakon što je crkva prestala biti u funkciji, tj. u vremenu nakon osnivanja Požeškog sandžaka 1538. godine (Mažuran, 1977: 165; Moačanin, 1997: 32) slijedom uvriježenog zadržavanja tradicije svetog mjesta (Krznar, 2012: 
odrasle osobe, od čega je minimalno 21 osoba muškog, a minimalno 14 osoba ženskog spola) koji su također najvjerojatnije bili ukopani u opatijskoj crkvi, a čiji je broj potvrđen antropološkom analizom izvankontekstualnog dislociranog ljudskog osteološkog materijala. Navedenom se broju mogu dodati još (barem) tri groba pronađena $\mathrm{u}$ grobnicama u sjevernom i južnom zvoniku. ${ }^{33}$ Svakako valja navesti i velik broj pokojnika koji je bio ukopan $\mathrm{u}$ kripti smještenoj $\mathrm{u}$ apsidi južne prigradnje $\mathrm{u}$ opatijsku crkvu. U toj je kripti bio odlagan i dio ljudskog osteološkog materijala pronađen u istraživanjima od 1986. do 2000. godine. Stoga antropološka analiza iz 2001. godine nije pogodna za izvođenje konkluzija o statusu pokojnika. No moguće je s oprezom zaključiti da su u toj kripti izvorno bili ukapani redovnici.

Slijedom navedenog, pretpostavlja se da su u opatijskoj crkvi te zvonicima pokopane barem 102 osobe. Prema količini izvankontekstualiziranog dislociranog ljudskog osteološkog materijala može se zaključiti da je razdoblje ukopavanja unutar opatijske crkve trajalo nekoliko stoljeća, tj. od osnutka do vremena njezina napuštanja, a možda i dulje. Navedeni broj nije neuobičajen. Naime, na brojnim je istraženim sakralnim kasnosrednjovjekovnim objektima uočena velika gustoća ukopa (Krznar, 2012: 27-28). Kako bi se tijekom duljeg razdoblja (u prosjeku nekoliko stoljeća) mogao prihvatiti što veći broj pokojnika koji su željeli biti pokopani unutar sakralnog objekta, redovito su uklanjani i/ili uništavani stariji grobovi. Katkad su zemaljski ostaci bili uklanjani i pohranjivani s pijetetom, no mnogo je češća bila praksa njihova ubacivanja u zapunu novoga groba.

Od 43 (tj. 45) istražena (i evidentirana) groba u unutarnjem prostoru opatijske crkve, 41 je moguće odrediti prema visini ukopa u dva sloja: viši (16 grobova) i niži (25 grobova). Naravno, dubina ukopa u ovom slučaju ne korelira nužno s vremenom ukopa.

Sa sigurnošću je in situ moguće potvrditi samo jednu nadgrobnu ploču, onu ukrašenu motivom škara izvedenih u niskom reljefu, koja je prekrivala grobnicu/ raku ukopanu u nekompaktni kameni živac u kojem je bila osoba ženskog spola, $\mathrm{u}$ trenutku smrti između 55 i 60 godina. Za sve ostale pronađene nadgrobne ploče ne mogu se sa sigurnošću utvrditi izvorne pozicije (Pleše, Sekulić 2014: 60-61).

Tijekom revizijskih istraživanja ni u jednoj zidanoj grobnici ili u grobnici/raki ukopanoj u nekompaktni kameni živac nisu pronađeni tragovi drvenog sanduka ni

38). Nadalje, moguće je pretpostaviti da su i neki pokojnici u višem sloju također bili pokopani nakon formalnog prestanka djelovanja opatijske crkve (npr. G 006/2014). No valja navesti i podatak da je broj subadulta na redovničkim grobljima statistički bio manji nego na župnima (Jungklaus, 2013:109). Tu pretpostavku treba razmotriti s veliki oprezom, zbog činjenice da je za sada statistički mali broj istraženih kasnosrednjovjekovnih groblja i grobova unutar župnih te redovničkih crkava antropološki obrađen. Diskrepanciju između broja rudinskih subadulta ukopanih u crkvi i navedenog podatka moguće je objasniti činjenicom da je rudinska opatijska crkva ujedno bila i župna (Buturac, 1934: 86).

33 Pronađeni ljudski osteološki materijal analiziran je 2013. godine u Antropološkom centru HAZU-a (Pleše i Sekulić, 2015). 
čavli. Stoga se može pretpostaviti da su pokojnici bili pokapani u grobno mjesto zamotani u tkaninu (Krznar, 2012: 30). Takva je praksa bila uobičajena tijekom kasnog srednjovjekovlja, jer je drveni sanduk bio često korišten samo za prijenos pokojnika od odra do grobnog mjesta, dok su izuzetak bili samo imućniji pokojnici (Krznar, 2012: 30).

$\mathrm{S}$ obzirom na vrlo mali broj nalaza u grobovima pronađenim u opatijskoj crkvi (za dva, odnosno četiri groba pronađena tijekom istraživanja 1987. i/ili 1988. godine ne postoji podatak jesu li u njima pronađeni nalazi; od šest istraženih grobova $u$ lađi crkve 2003. godine, pet ih je imalo nalaze samo u zapunama, dok je samo u jednom pronađen ostatak tkanine protkane zlatnim nitima; od 35 istraženih grobova 2014. godine, samo su u pet grobova pronađeni nalazi: ostatak ukrasa na ovratnom otvoru haljine izrađen od lanenih traka s motivom križeva izvezenih kombinacijom metalnih i svilenih niti, brončana kopča, srebrna puceta, srebrni denar Žigmunda Luksemburškog, brončana kopča, maleni kružni predmet od bakrene legure nejasne namjene i srebrni prsten), moguće je navesti samo neke opće podatke o opremanju pokojnika. Kao što navodi S. Krznar, nakon smrti je pokojnik bio pažljivo opran, pomazan te omotan tkaninom, koja je pak kod glave i nogu bila pričvršćena vezicama, iglama ili šivanjem (Krznar, 2012: 30). No može se pretpostaviti da je tkanina bila pričvršćena i kopčama, što bi pojasnilo mjesta nalaza dviju brončanih kopči u grobovima (kod desnog skočnog zgloba i kod lijevog koljena).

Iako je prema brojim srodnim primjerima poznato da je položaj groba, tj. grobnice unutar sakralnog objekta imao važnu ulogu te je shodno tome bio i adekvatno materijalno vrednovan (Krznar, 2012: 26-27; Jungklaus, 2013: 105), ipak rudinske pokojnike nije moguće staleški odrediti isključivo prema tom načelu.

Pri interpretiranju staleške pripadnosti pokojnika ukopanih u rudinskoj opatijskoj crkvi svakako treba voditi računa o ustaljenim, ali znanstveno (ponajprije statistički) neutemeljenim, premisama izvedenim na temelju interpretiranja dosadašnjih antropoloških analiza degenerativnih promjena na ljudskom osteološkom materijalu. To se ponajviše odnosi na povezivanje degenerativnih promjena kao posljedica teškog fizičkog rada (npr. osteoartritis, Schmorlovi defekti i dr.) uz najniži stalež (kmetovi). No valja imati na umu da je jedina distinkcija između dnevnih poslova niskog i nižeg plemstva i onog kmetskog bila u pravnoj odrednici podređenosti. Ta pretpostavka potvrđena je s 15 grobova pronađenih u rudinskoj opatijskoj crkvi. Slijedom navedenog, premise o klasnoj pripadnosti pokojnika te povezivanju degenerativnih promjena s aktivnostima i određenim staležom nužno je sagledati s velikim oprezom. ${ }^{34}$

34 Ako je moguće suditi prema fotografijama, svi su ljudski osteološki nalazi ostali nakon istraživanja koje je vodio GMP in situ: dio je bio ostavljen u zidanim grobnicama, a dio je prekriven plastičnom folijom. Ljudski je osteološki materijal dostavljen na analizu stručnjacima na Odjelu za arheologiju 
Tijekom revizijskih arheoloških istraživanja 2014. godine pronađena je i manja količina pokretnih arheoloških nalaza. Iako je broj nalaza relativno mali, od čega je samo šest pronađeno unutar grobnih cjelina, vrlo su raznovrsni i indikativni. ${ }^{35}$

Najzastupljeniji su nalazi kovanog novca (pet komada), ${ }^{36}$ datirani od kraja 13. do trećeg desetljeća 16. stoljeća: brončani denar Friedricha II. (1218.-1250.), brončani denarić (denaro piccolo) (Padova, 1271.-1328.), denar (obrezan na veličinu obola) Žigmunda Luksemburškog (1387.-1437.), srebrni denar Vladislava II. Jagelovića (1490.-1516.) i bakreni denar (suberat) Ludovika II. Jagelovića (1516.-1526.).37

Najstariji pronađeni nalaz svakako je brončana S-karičica, koju je moguće oprezno datirati u 12. stoljeće. Nažalost, pronađena je u zasipu kod srednjeg temelja baze u južnom redu stupova/ stubova rudinske opatijske crkve pa je zato nije moguće kontekstualizirati. $^{38}$

Slika 5

HAZU-a tek 2001. godine. Dostavljen je bez signatura pa ga nije bilo moguće povezati ni s vrlo oskudnom dokumentacijom. Nadalje, nije poznato je li analizirani materijal prikupljen samo u opatijskoj crkvi i oko nje ili i iz grobne kapele. Prema izvještaju M. Šlausa (Šlaus, 2002), dostavljeni su uzorci iz „pojedinačnih grobova", što čini ukupno 81 kostur (59 muškaraca, 13 žena i devetero djece). M. Šlaus navodi da uzorci potječu i iz dviju masovnih grobnica u kojima je minimalni broj osoba određen na temelju broja uščuvanih proksimalnih epifiza lijevih femura.

Predmetni je materijal obradio i M. Novak (Novak, 2013: 115-136) koji nije raspolagao podacima na koji je način bio prikupljen rudinski ljudski osteološki materijal te kako je bio zbrinjavan od istraživanja do trenutka kad je odnesen iz Rudine te je izveo zaključke u skladu s mogućnostima.

35 Svi metalni nalazi obrađeni su na Odjelu za restauriranje kopnenih arheoloških nalaza HRZ-a, dok je nalaz dekorativnog metalnog okovratnika obrađen na Odjelu za tekstil, papir i kožu HRZ-a.

36 Analizu kovanog novca proveli su kolege dr. sc. Tomislav Bilić i Miroslav Nađ (obojica iz Arheološkog muzeja u Zagrebu), na čemu im srdačno zahvaljujemo.

37 Srebrni denar Vladislava II. Jagelovića, bakreni suberat Ludovika II. Jagelovića te brončani denar Friedricha II. pronađeni su u zasipu uz sjevernu stranicu zidane grobnice smještene između srednje i istočne baze južnog reda stupova/stubova. Vremenski se s tim nalazima podudara kovani novac pronađen tijekom arheoloških istraživanja 2003. godine: srebrni denar Žigmunda Luksemburškog (1387.-1437.) i srebrni denar Antonija II. Pancierea (1402.-1411.) (Tomičić, 2013: 44-45).

38 Treba napomenuti da su u prethodnim istraživanjima rudinske opatije pronađene još dvije S-karičice. Prva je pronađena 1988. (najvjerojatnije) u predvorju crkve (Sokač Štimac, 1988a: 1-6; Sokač Štimac, 1988b: 1-3; Sokač Štimac, 1997: 20), a druga 1989. godine s vanjske strane apside (u zapisima se ne navodi koja je to apsida) (Sokač Štimac, 1989a: 1-8; Sokač Štimac, 1989b: 1-2; Sokač Štimac, 1989c: 5-32). 


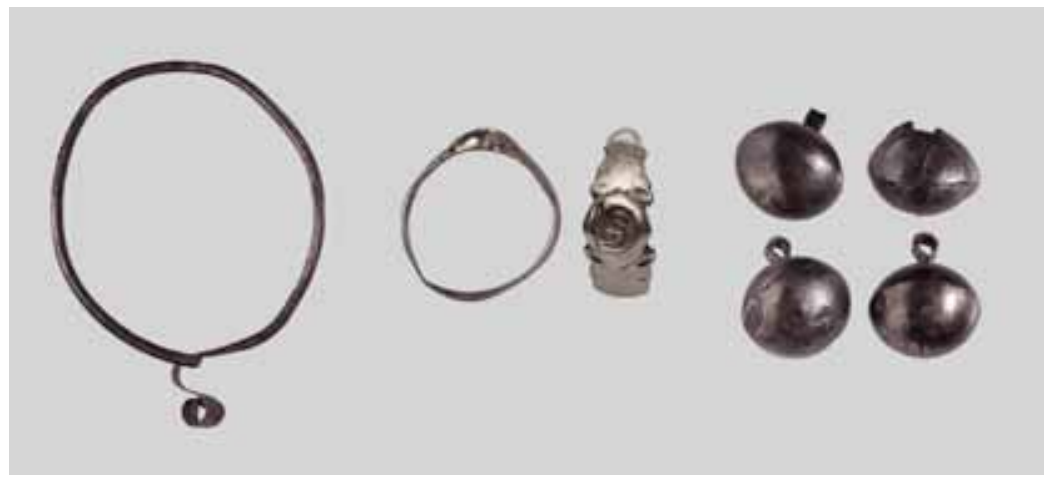

Slika 5. Nalazi (S-karičica, prsten i puceta) pronađeni u rudinskoj opatijskoj crkvi tijekom revizijskih istraživanja 2014. godine. Snimka: J. Šudar, 2015. (arhiva HRZ-a)

U 14. i 15. stoljeće moguće je, shodno komparativnom materijalu (Gabór, 2006: 111-130), datirati nalaz dviju brončanih kopči. ${ }^{39}$ Slika 6

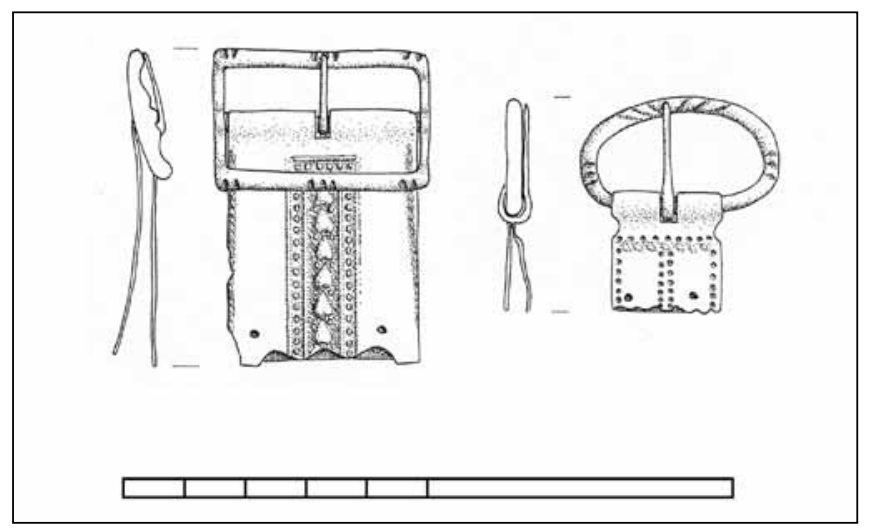

Slika 6. Kopče pronađene tijekom revizijskih istraživanja 2014. godine u rudinskoj opatijskoj crkvi. Crtež: M. Krmpotić, 2015. (arhiva HRZ-a).

Od 14. do 16. stoljeća moguće je datirati srebrna puceta te ukras okovratnog dijela haljine izrađen od lanenih traka s motivom križeva izvezenih kombinacijom metalnih (pozlaćena metalna spiralna ovojnica i svilena srž) i svilenih niti. Slike 5, 7 i 8

39 Gotovo identična kopča pronađena je u arheološkim istraživanjima 1980. godine uz vanjsko pročelje grobne kapele (Sokač Štimac, 1986c: 30, T III, br. 10). 


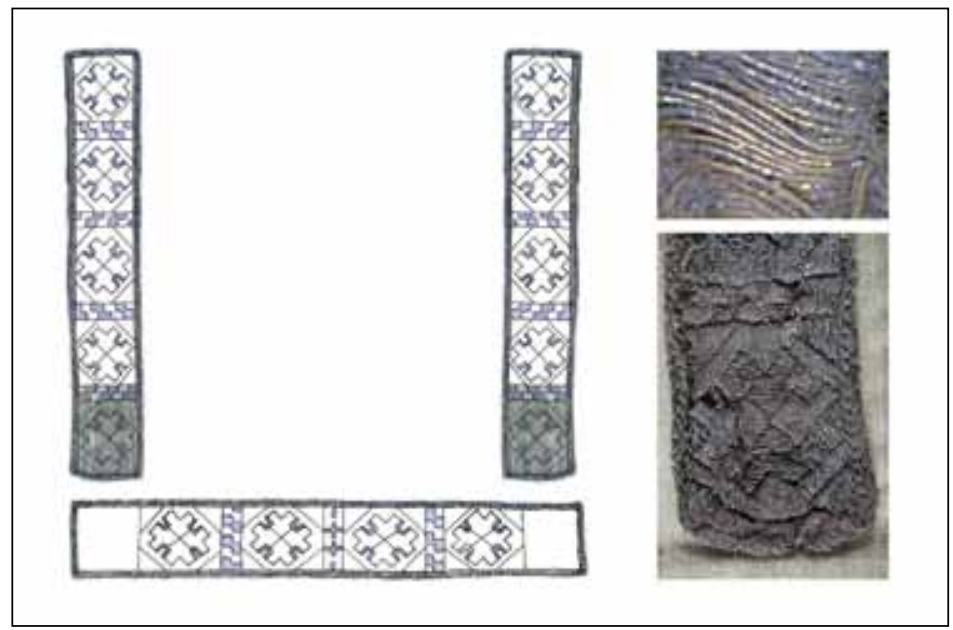

Slika 7. Grafički prikaz i makro snimke tri vezena fragmenta. Snimke: G. Tomljenović, 2015. (arhiva HRZ-a)

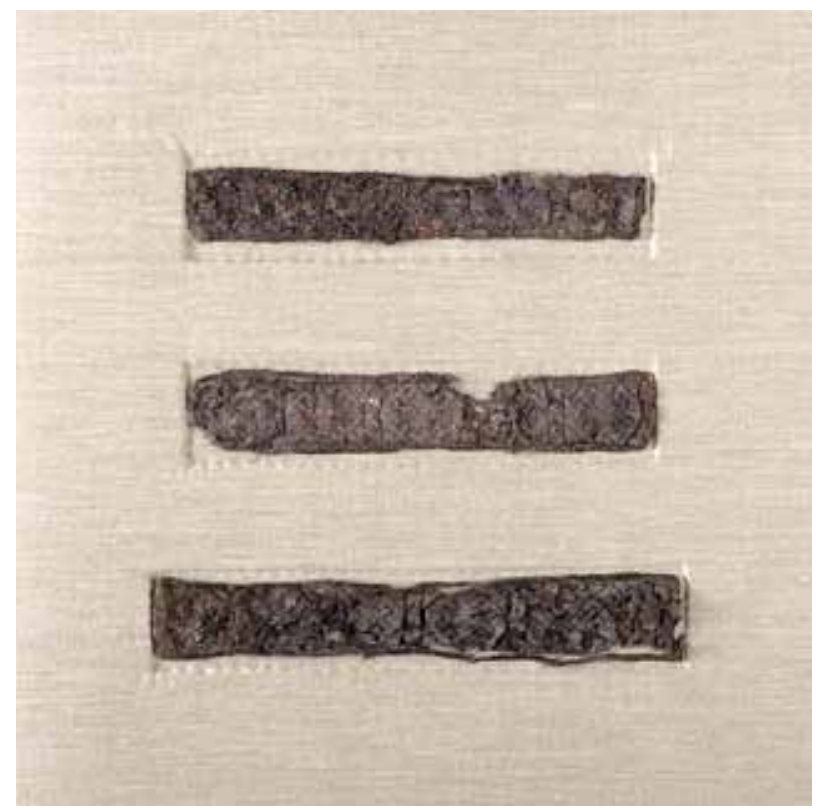

Slika 8. Tri vezena fragmenta nakon dovršetka konzervatorsko-restauratorskih radova. Snimka: G. Tomljenović, 2015. (arhiva HRZ-a)

Nešto šire je moguće datirati tri prstena pronađena tijekom revizijskih istraživanja 2014. godine. Srebrni se prsten može datirati u 15. ili 16. stoljeće, brončani prsten 
bez ukrasa u vrijeme od 11. do 16. stoljeća, a brončani prsten, izrađen od čvrsto namotane tanke brončane žice s kukicom, u vrijeme od 13. do 16. stoljeća. Slika 5

Osim opisanih nalaza, $\mathrm{u}$ zasipu je $\mathrm{u}$ revizijskim istraživanjima rudinske opatijske crkve pronađena i manja količina ulomaka keramičkih predmeta, koje je moguće datirati u 15. stoljeće. ${ }^{40}$ Nadalje, u zasipu su pronađena i dva mala ulomka prozorskih ostakljenja te 13 malih ulomaka fresaka s geometrijskim motivima izvedenim bijelom, plavom, crvenom, žutom i zelenom bojom.

Svi dosadašnji (rijetki) opisi i analize rudinske opatije rađeni su prema shematskom, nekotiranom tlocrtu te šturim opisima D. Sokač Štimac. ${ }^{41}$ S. Sekulić Gvozdanović zaključila je da je rudinska opatija bio utvrđeni objekt na dvije etaže. Kao što je navedeno u tekstu, određivanje rudinske opatije kao utvrđenog objekta zasnovano je na navodu Gj. Szabe o dubokom opkopu te prema jednoj puškarnici. Nadalje, zaključak da je objekt imao dvije etaže počiva na opisu stuba koje nisu ucrtane na tlocrtnoj shemi (Sekulić Gvozdanović, 2007: 39-42). Opis opatije B. Vučića Šnepergera znatno je suzdržaniji i temelji se na zaključcima da su izostala prava istraživanja graditeljske baštine (Vučić Šneperger, 2013) te da nije riješeno pitanje faznosti gradnje.

Prema rezultatima dosadašnjih revizijskih istraživanja, moguće je navesti neke nove spoznaje o prostornoj organizaciji rudinske opatije sv. Mihovila arkanđela, za sada jedine $\mathrm{u}$ kasnosrednjovjekovnom prostoru slavonsko-srijemskog međurječja kojoj poznajemo arhitektonski ustroj (Andrić, 1998: 33).

Kako bi tlocrtna dispozicija bila što jasnija, treba spomenuti i druge benediktinske opatije srodne prostorne organizacije: to su npr. one u Cluj-Mănăturu (Ko-

40 Na pomoći pri datiranju pronađenih ulomaka keramičkih predmeta zahvaljujemo kolegi Andreju Janešu (HRZ).

41 D. Sokač Štimac istraženu je arhitekturu opisala u nekoliko radova. Smatra da je rudinska opatijska crkva "tipična benediktinska bazilika dužine $14 \mathrm{~m}$ i širine $8 \mathrm{~m}$, s karakterističnim svetištem u obliku tri polukružne apside i tri para stupova u unutrašnjosti“. Nadalje, „unutrašnjost je građena samo lomljenim kamenom, jer su zidovi bili oslikani raznobojnim freskama“, pri čemu je u „središnjem dijelu crkve bilo prikazano Oplakivanje Kristovo". Autorica smatra da je "crkva jedinstvena pojava u našoj romaničkoj arhitekturi s geometrijskom pravilnosti tlocrta, komponiranog u proporcijama 'zlatnog presjeka'“. (Sokač Štimac, 1997: 21 Sokač Štimac, 2013: 5) Nadalje, autorica navodi da je „prvobitni ulaz u crkvu bio na jugu gdje su otkrivene monumentalne polukružne stube u četiri reda, pa se na taj način olakšao prilaz. Kasnije je ulaz u crkvu bio iz predvorja, na zapadu“" (Sokač Štimac, 1997: 20).

Opatijski je sklop D. Sokač Štimac također opisala vrlo šturo. Navodi da se sjeverno od crkve nalazi „četvrtasto dvorište visine $1 \mathrm{~m}$ i dimenzija $12 \times 12 \mathrm{~m}$. Unutar njega kameni zid čine prostor filterne cisterne za vodu $(8 \times 7,8 \mathrm{~m})$. U sredini je bunar od kamena, promjera $0,8 \mathrm{~m}$, a oko njega kružni zid od cigli visine $2 \mathrm{~m}$. Oko dvorišta je trijem koji je na sve četiri strane popločen manjim ciglama koje su složene u obliku riblje kosti. Na istočnoj strani zida je pronađen romanički kapitel, što ukazuje da je klaustar istovremen s crkvom. Uz istočni hodnik klaustra nalazi se kapitulska dvorana izduženog oblika, uz samostansku kapelu. Na sjeveru i zapadu otkopani su dijelovi samostana. Blagovaonica (refektorij) je duga 15 i široka 5,5 m, a između nje i kuhinje (gdje je pronađeno najviše ostataka kuhinjskog posuđa) nalazi se uski i visoki prozor kroz koji se dodavala hrana. Stube pronađene na zapadnom zidu blagovaonice ukazuju da je samostan imao kat, na kojem je vjerovatno bila spavaonica." Autorica nadalje zaključuje da je „samostan bio utvrđen“. (Sokač Štimac, 1997: 21, Sokač Štimac, 2013: 12-13). 
lozsmonostor), Bizereu, Hronský Beňadiku (Garamszentbenedek), Dombováru (Kaposszentjakab), Csongradu (Ellés) i Somogyváru. ${ }^{42}$ Gotovo su sve navedene opatijske crkve (s izuzetkom one u Bizereu) trobrodne i imaju zvonike na zapadnom pročelju, a organizacija drugih prostora bila je također prilagođena morfologiji terena.

Rudinska je opatija bila organizirana oko pravokutnog klaustra, s crkvom u jugoistočnom dijelu sklopa, dok je (grobljanska) kapela bila smještena 40-ak metara jugozapadnije. Slika 9

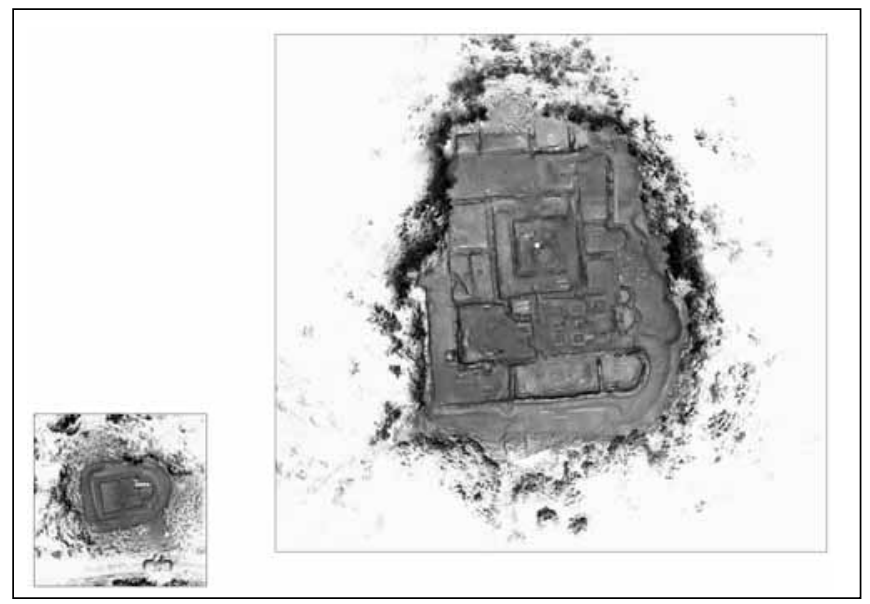

Slika 9. Georeferencirani 3D model rudinske opatije sv. Mihovila arkanđela. Izrada: Vektra d.o.o., 2014. (arhiva HRZ-a)

Trobrodna crkva, ${ }^{43}$ zaključena na istoku trima polukružnim apsidama, bila je podijeljena $u$ tri lađe sa šest masivnih baza raspoređenih $u$ dva reda. Za sada nije

42 Rusu, Burnichioiu, 2011; Tomičić, 2013: 49-59; Buzás, 2012; Levente, 2016: 173-189; http://www.sulinet.hu/oroksegtar/data/megyek_oroksege/Csongrad_megye.htm;http://www.medievistica.ro/ texte/arheologie/starile/RezervatiaBizere/Panou2a.jpg.

Iako su istraživanja još u ranoj fazi, sličnost u prostornoj organizaciji uočena je i u benediktinskoj opatiji sv. Margarete u Bijeloj (Janeš i Sekulić, 2014).

${ }_{43}$ Za gradnju rudinske opatijske crkve korištene su dvije vrsta kamena, određene mineraloško-petrografskom analizom te makroskopskim opažanjima, kao kataklastični amfibolit te biokalkarenit tipa pekston (packstone) (geološke starosti miocen, najvjerojatnije baden). Za izradu lijepo obrađenih klesanaca na vanjskom i unutarnjem pročelju zidova korišten je biokalkarenit tipa grejnston (grainstone) (geološke starosti miocen, najvjerojatnije baden). Analizirana su još dva uzorka kamena prikupljena u temeljima baza stupova/stubova, koji su određeni kao biokalkarenit do biokalkrudit floutston (floatstone) do frejmston (framestone) (geološke starosti miocen, najvjerojatnije baden) te biokalkarenit tipa pekston do floutston (floatstone) (geološke starosti miocen, najvjerojatnije baden). Navedeni je materijal bio vezan žbukom žućkasto-sive boje te izrazito jake čvrstoće. Vidljiva su zaobljena i uglata zrnca punila (pretežito bijele, sive, žućkaste i crne boje), mjestimično sitnije bijele grudice karbonatnog veziva te usitnjena opeka (odnos veziva i punila: $77,6 \%: 22,4 \%$, tj. oko $3,5: 1$ ). 
moguće potvrditi jesu li se na tim bazama $(1 \times 1 \mathrm{~m})$ nalazili stupovi ili stubovi. Zaključno s dovršetkom revizijskih istraživanja 2014. godine nije pronađen ni jedan ulomak stupa (ni in situ ni kao spolija u okolnim selima).

Zbog spomenute metode konzerviranja nije moguće razlikovati temelje od zidova, a shodno tome nije moguće sa sigurnošću odrediti ni jednu poziciju vrata. No svakako valja izdvojiti južni temelj crkve širine od $1,65 \mathrm{~m}$. Za sada nije moguće objasniti tu širinu, no s oprezom se može pretpostaviti da je rješenje u njegovu odnosu s južnim temeljem južnog zida dogradnje uz rudinsku opatijsku crkvu.

Crkva je s istočne strane zaključena dvjema manjime apsidama (sjeverna i južna) te većom (središnja) apsidom. Širina zida apsida, kao i dijela južnog zida crkve, rezultat je suvremene rekonstrukcije.

Unatoč provedenim revizijskim istraživanjima, nije moguće zaključiti kako je bila izvedena podnica unutar crkve. D. Sokač Štimac smatra da je podnica bila napravljena od kamenih ploča s reljefnim prikazom škara i sjekira (Sokač Štimac, 2013: 6). Tijekom revizijskih istraživanja pronađene su dvije kamene ploče za koje se oprezno može pretpostaviti da su imale namjenu podnog popločenja. No nikako nije moguće potvrditi jesu li uistinu imale tu namjenu, te ako jesu, je li podnica bila sastavljena isključivo od takvih ploča i onih nadgrobnih ili je pak bio korišten i neki treći format.

Zbog već spomenute loše sačuvanosti zidova crkve, ne može se mnogo reći o njihovoj strukturi. Jedini dobro sačuvani dio jest zapadni dio južnog zida na kojem je vidljivo da su za gradnju vanjskih slobodnih pročelja bili korišteni lijepo obrađeni, krupniji klesanci.

Nadalje, pretpostavlja se da su zidovi bili ukrašeni arhitektonskom figuralnom plastikom i profilacijama (već opisane slijepe arkade, klesanci s tzv. dijamantnim ukrasom i dr.). Nažalost, ne zna se njihov točan razmještaj.

Pregledom arhitektonskih profilacija te u skladu s rezultatima dosadašnjih istraživanja, unutar te oko crkve nije pronađeno ni jedno svodno rebro. Stoga se može pretpostaviti da je unutrašnjost crkve bila natkrivena tabulatom. Ujedno nije moguće zaključiti kako su bili raspoređeni svijetli otvori. Shodno tome, moguće je prihvatiti pretpostavke B. Vučića Šnepergera da je središnja lađa bila viša od bočnih, da su apside bile visoke koliko i sam brod, da je krovište bilo nad glavnom lađom dvostrešno, a nad onim bočnim jednostrešno te da je osvjetljenje bilo riješeno $u$ formi tzv. bazilikalnog presjeka.

Na zapadnom pročelju crkve nalazila su se dva masivna zvonika, oba konzervirana cementnim mortom. Sjeverni je zvonik u relativno dobrom stanju, dok je južni rekonstruiran prema jedva vidljivim tragovima na bočnim zidovima. Prostor između ta dva zvonika $(3,70$ × 2,50 m) ujedno je i ulazni prostor u crkvu. 
Zbog već spomenutog problema uništenosti zidne mase nije moguće zaključiti jesu li se vrata za ulazak u zvonike nalazila na vanjskom pročelju ili se u njih ulazilo iz unutrašnjosti crkve.

Sa zapadne strane opatijske crkve nalazi se prostrano pravokutno predvorje $(6,75 \times$ oko $8,1 \mathrm{~m})$ koje $\mathrm{s}$ istočne strane određuju zapadna pročelja zvonika. aj je prostor, (vjerojatno) dograđen tijekom kasnije građevinske faze, bio ojačan pravokutnim potpornjima na južnom dijelu zapadnog pročelja te na sredini južnog. Visinu izvornog hodnog sloja moguće je odrediti isključivo u korelaciji s hodnim slojem u opatijskoj crkvi.

Uz južnu stranu opatijske crkve tijekom kasnije građevinske faze dograđen je nešto duži, pravokutni objekt zaključen na istočnoj strani velikom, blago nepravilnom polukružnom apsidom. Izgrađen je od relativno neurednih lomljenjaka usloženih $u$ ne pretjerano uredne redove i povezanih velikom količinom veziva loše kvalitete. Taj je mlađi objekt podijeljen na dva nejednaka dijela (istočni i zapadni). Zapadni, znatno veći dio mlađeg objekta jest pravokutna prostorija $(11,85 \times 4,40 \mathrm{~m})$. Je li ta prostorija bila dodatno podijeljena, za sada se ne zna, zbog velike količine urušene zidne mase. $U$ arheološkim istraživanjima koje je vodio GMP, u sjeverozapadnom dijelu te prostorije navodno su pronađene stube. Nažalost, taj element nije dokumentiran, a nije ga, zbog navedenog razloga, bilo moguće potvrditi. Ni u tom prostoru (za sada) nije moguće odrediti izvornu kotu hodnog sloja.

Istočni, manji dio mlađeg objekta dodatno je podijeljen na dva dijela (istočni i zapadni). Prema fotografijama je razvidno da se s unutarnje strane apside nalazio istak, za koji se može s oprezom pretpostaviti da je imao namjenu sedilije, te pravokutna struktura, koja se prema smještaju i izgledu može odrediti kao zidani dio oltara.

Taj je objekt bio u svim dosadašnjim radovima interpretiran kao gotička dogradnja, tj. gotička kapela. $S$ obzirom na nalaz masovne grobnice $u$ njegovu istočnom dijelu, ta se pretpostavka za sada prihvaća vrlo oprezno. Prema dostupnim podacima nije moguće zaključiti je li taj prostor bio svođen ili prekriven tabulatom. Unatoč znatnoj sačuvanoj visini zidova toga objekta, ni na jednom dijelu nije sačuvan ni jedan otvor. Nadalje, prema trenutačnom stanju istraženosti, može se oprezno zaključiti da je južni zid te mlađe dogradnje ujedno i južna vanjska građevinska linija rudinske opatije.

Uz južnu stranu navedenoga objekta jasno je vidljiv masivni temelj i dio zida znatno drugačije strukture gradnje. Ta je struktura ojačana na zapadnom i istočnom dijelu dvama nejednakim potpornjima (?). Kako se sjeverni dio temelja u cijelosti nalazi pod južnim zidom južne prigradnje uz opatijsku crkvu, opravdano se može pretpostaviti da je ta struktura starijeg datuma. 
Određen zapadnim pročeljem mlađeg objekta uz južni zid crkve, južnim zidom njezina predvorja te jednostavnim zidom s južne i zapadne strane, nalazi se pravokutni prostor $(10,9 \times 4,85 \mathrm{~m})$ koji se nastavlja dalje prema sjeveru, prateći zapadno pročelje predvorja te zapadno pročelje zapadnog opatijskog krila (prosječna širina $3,30 \mathrm{~m}$; istražena dužina $9,30 \mathrm{~m}$ ). Ni u tom prostoru nije moguće odrediti kotu izvornog hodnog sloja.

Može se pretpostaviti da je opisani prostor izgrađen istovremeno s južnom prigradnjom uz opatijsku crkvu. Iako nije moguće datirati tu građevinsku fazu, razvidno je da je $u$ to vrijeme opatija bila proširena prema jugu i zapadu. Osnovna obilježja te građevinske faze su tanji (prosječna širina mlađih zidova $0,75 \mathrm{~m}$, prosječna širina starijih zidova $0,95 \mathrm{~m}$ ) i znatno nemarnije izgrađeni zidovi, ali se ne može zaključiti je li taj prostor bio natkriven ili nije.

Cijela je opatija organizirana oko prostranog pravokutnog klaustra. U sredini se nalazi dvorište $(6,30 \times 7,40 \mathrm{~m}) \mathrm{s}$ bunarom (promjer $0,80 \mathrm{~m})$. Svi unutarnji zidovi (širina $60 \mathrm{~cm}$ ) dvorišta u izuzetno su lošem stanju. Parterni dio prostora iskorišten je za kružnu cisternu izgrađenu od opeke koja zauzima gotovo cijelu njegovu površinu. Tijekom istraživanja su in situ potvrđena i četiri kamena poklopca. Nije poznato kojim je materijalom bila izvedena hodna ploha dvorišta, a za sada nije moguće odrediti njezinu izvornu visinsku kotu.

Dvorište je sa sve četiri strane određeno hodnicima (istočni i zapadni hodnik dugački su 13,75 m i široki 2,2 m, dok su sjeverni i južni dugački 7,5 m i široki 2,55 m). Tijekom arheoloških istraživanja, koja je proveo GMP, pronađena je podnica od opeke složena $u$ obliku „riblje kosti“ $u$ istočnom hodniku. Nažalost, podnica nije konzervirana pa je stoga $u$ cijelosti propala.

U istraživanju su potvrđena tri opatijska krila, sva izgrađena od krupnijeg, nemarno obrađenog lomljenjaka povezanog obilnim korištenjem veziva slabije kvalitete. S obzirom na oskudno sačuvane podatke, ne može se utvrditi jesu li krila imala kat ili nisu, koje su bile namjene pojedinih prostorija, jesu li bile svođene ili natkrivene tabulatom, koje su im bile izvorne kote hodnih slojeva te na kojim su se mjestima nalazili otvori.

Istočno krilo opatije bilo je podijeljeno na četiri prostorije. Najjužna prostorija bila je izravno povezana s opatijskom crkvom te se može sa sigurnošću odrediti kao sakristija (unutarnje dimenzije: 4,10 × 3,80 m; s južne je strane sakristija bila određena istočnim dijelom sjevernog zida opatijske crkve). U svrhu komunikacije s crkvom može se zaključiti da su se vrata nalazila na njezinu zapadnom zidu. Nadalje, $u$ sakristiji su bile in situ sačuvane freske ${ }^{44}$ na zapadnom i sjevernom zidu. Druga pro-

44 U istraženom dijelu sakristije pronađen je oslik (kvadratna polja plavosive i ružičaste boje, razdijeljena bijelom trakom) uz cijeli donji dio zapadnog zida (Sokač Štimac, 2013: 7). Te su freske konzervirane in situ iste godine, a radove su izveli djelatnici Restauratorskog zavoda Hrvatske. Posebno je zanimljiv 
storija $\mathrm{u}$ istočnom opatijskom krilu nalazi se sjeverno od sakristije. Ta jednostavna, relativno mala pravokutna prostorija (unutarnje dimenzije 4,10 x 3,50 m) na istočnoj je strani zaključena polukružnom apsidom koja cijelom svojom dubinom izlazi izvan granica istočne opatijske građevinske linije (pretpostavljena kapela). Sjeverno od nje nalazi se manja, blago trapezoidna prostorija (3,60-3,75 x 2,20 m). Zbog manjka podataka o pronađenim pokretnim arheološkim nalazima (za sada) nije moguće odrediti njezinu namjenu. Četvrta, najsjevernija prostorija istočnog opatijskog krila također je trapezoidnog oblika (širina na južnom dijelu 3,80 m, širina na sjevernom dijelu 4,40 m, dužina 7,15 m). Na njezinu istočnom zidu in situ je sačuvan jedini do sada poznati otvor na cijeloj rudinskoj opatiji (strijelnica ljevkastog tlocrta).

Sjeverno krilo rudinske opatije podijeljeno je na (barem) tri prostorije. Kako arheološka istraživanja toga dijela opatije nisu bila provedena do kraja, ne može se zaključiti kako da je to krilo bilo određeno na svojoj zapadnoj strani. Najistočnija prostorija također je blago trapezoidna $(5,40 \times 4,80-5,10 \mathrm{~m})$. Sjeverno vanjsko pročelje ojačano je dvama masivnim pravokutnim potpornjima između kojih su vidljive dvije reške koje određuju prostor širine $2,20 \mathrm{~m}$. S obzirom na dimenziju otvora, moguće je oprezno pretpostaviti da su se na tom mjestu nalazila glavna ulazna vrata u opatiju. Naime, na sjevernoj je strani platoa najpogodniji teren za pristupnu komunikaciju opatiji. Drugoj (do sada) istraženoj prostoriji sjevernog opatijskog krila za sada se ne mogu odrediti dimenzije (istražena dužina $14,2 \mathrm{~m} \times 5,80 \mathrm{~m}$ ). ${ }^{45} \mathrm{Na}$ zapadnom dijelu sjevernog zida nalazi se treća (do sada istražena), mala kvadratna prostorija sjevernog opatijskog krila $(2,60$ × 2,65 m). Ta prostorija cijelom dužinom izlazi izvan gabarita sjeverne građevinske linije rudinske opatije. Tlocrtnu dispoziciju toga dijela opatije bit će moguće potvrditi tek daljnjim istraživanjima.

Zapadno opatijsko krilo podijeljeno je na (barem) tri prostorije. Sa sjeverne je strane određeno velikom pravokutnom prostorijom $(5,95 \times 6,30 \mathrm{~m})$. U južnom dijelu ovog krila nalazi se prostorija gotovo identičnih dimenzija onoj sjevernoj $(5,85 \times 6,45$ $\mathrm{m})$. Ta je prostorija bila podijeljena na dvije ili tri manje, no prema zatečenom stanju za sada nije moguće odrediti točan broj.

Četrdesetak metara od opatije u smjeru jugozapada nalazi se manji sakralni objekt (bruto površina oko $49 \mathrm{~m}^{2}$ ). S obzirom na njegovu tlocrtnu dispoziciju, smje-

nalaz komada freske pronađen u lađi opatijske crkve s prikazom ljudskog lakta koji je interpretiran kao Oplakivanje Kristovo. Prema mišljenju L. Ivančević Španiček, crkva i sakristija bile su ukrašene freskama s motivima romba, ljiljana i kvadrata crvene i plave boje obrubljenima bijelom bojom. Smatra i da je u crkvi bio prikazan ciklus Kristovih muka, koje povezuje s prikazima u zvoniku crkve sv. Marije u Zadru (Ivančević Španiček, 1997: 26).

45 Zapadni dio sjevernog zida te prostorije ujedno je i vanjski zid rudinske opatije. Struktura koja se vidi sjeverno od predmetnog zida, na nacrtu T. Papića (pismohrana GMP-a) ucrtana je kao zid, dok je na geodetskoj snimci (Kučinić d.o.o.,pismohrana GMP-a) nema. Prema zatečenom stanju moguće je utvrditi da je ispravan potonji nacrt, jer je ta struktura nastala tijekom arheoloških istraživanja odlaganjem kamena iz urušene mase. 
štaj, brojne istražene grobove te na srodnost s takvim objektima drugih benediktinskih opatija (Cluj-Mănăștur, Bizere, Hronský Beňadik, Dombovár, Csongrad i Somogyvár) može se zaključiti da je to bila grobljanska kapela. ${ }^{46}$

Rudinska kapela oblikovana je kao manji jednobrodni objekt (vanjske dimenzije: 9,25 x 8,00 m; unutarnje dimenzije: lađa 5,75 x 4,45 m, svetište 1,9 x 2,65 m, širina ramena $0,85 \mathrm{~m}$ ) zaključen na istoku polukružnom apsidom. Na sjevernom i južnom zidu je po jedna plitka pravokutna lezena. U grobljanskoj kapeli pronađena je samo jedna zidana grobnica. Nažalost, ne može se utvrditi kako je bila izvedena podnica i na kojoj se visini nalazila, kako su bili raspoređeni otvori (tijekom istraživanja nije pronađena ni jedna arhitektonska profilacija) te je li kapela bila svođena ili natkrivena tabulatom. Kapela je u cijelosti konzervirana cementnim mortom 1982. godine (radove je izvelo Stambeno-komunalno poduzeće Požega), čime su zauvijek izbrisani svi tragovi koji su mogli odgovoriti na navedena pitanja.

\section{O konzerviranju i prezentiranju}

Kad je ustanovljeno stanje rudinske opatije te nakon usvajanja zaključka da će se sva buduća revizijska istraživanja provoditi isključivo ako je moguće osigurati subsekventno konzerviranje (uz prethodno detaljno dokumentiranje metodom 3D laserskog skeniranja), radovi su počeli 2014. godine. Planirani su prema anticipiranoj mogućnosti osiguravanja financijskih sredstava.

Tijekom 2014. i 2015. godine konzervirana je opatijska crkva. Sve zidne strukture bez kojih ne bi bilo moguće prezentirati objekt su konzervirane, nakon što je s njih uklonjen cementni mort (temelji zidova, baze stupova/stubova). $S$ obzirom na visok stupanj dilapidacije, na nekim dijelovima primijenjena su neutralna rješenja, proizišla iz konstruktivne logike. Jednakim načinom osmišljena su i rješenja kojima su se premostili poremećeni visinski odnosi proizašli iz prethodnih radova na saniranju zidne mase. Iako ta rješenja više nisu vidljiva, ostala su nedirnuta kao svjedočanstvo prijašnjih konzervatorskih rješenja. Poslije osiguravanja sigurne osnove za prezentiranje opatijske crkve, a poštujući financijski zahtjevan idući korak rekonstrukcije zidne mase, svi konzervirani zidovi zaštićeni su reverzibilnom krunom.

Nadalje, usuglašeno je da prezentiranje grobnica na poziciji kao što je ova rudinske opatije nije poželjno iz nekoliko razloga: od nedovoljno jasno artikuliranih vrijednosti do nemogućnosti održavanja i osiguravanja sigurnosti posjetitelja. Stoga su sve grobnice i grobne rake adekvatno tamponski zaštićene i prezentacijski vraćene izvorniku (tj. ispod hodnog sloja). Izuzetak su one za koje je bilo moguće dokazati da su imale nadgrobne ploče, pa su one i vraćene na izvorne pozicije.

46 D. Sokač Štimac navodi da je taj objekt ",drugi pronađeni i istraženi starohrvatski sakralni arhitektonski spomenik na tlu sjeverne Hrvatske“. (Sokač Štimac 1980: 1-5; Sokač Štimac 1986c: 8, 16-18; Sokač Štimac, 1997: 19; Sokač Štimac, 2013: 3). 
Ujedno je u crkvi rekonstruirana visina hodnog sloja, određena prema međuodnosu visina vrha temelja, najnižeg reda klesanaca južnog zida crkve te pretpostavljene prosječne debljine hodnog sloja. Slike 10 - 13

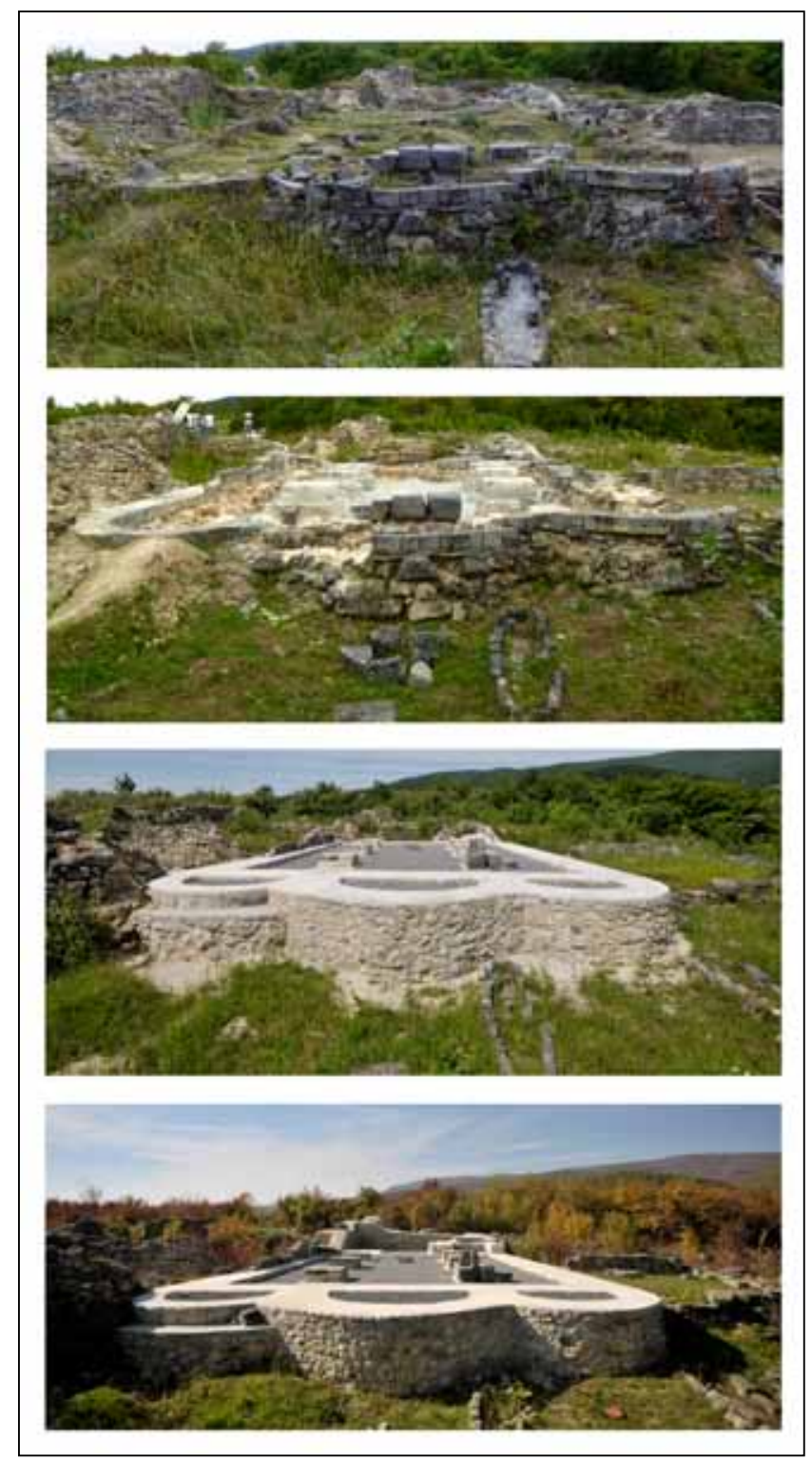

Slika 10. Pogled s istoka na rudinsku opatijsku crkvu prije, tijekom i nakon prve faze konzervatorsko-restauratorskih građevinskih radova.

Snimke: T. Pleše, 2013., 2014., 2015. i 2017. (arhiva HRZ-a) 


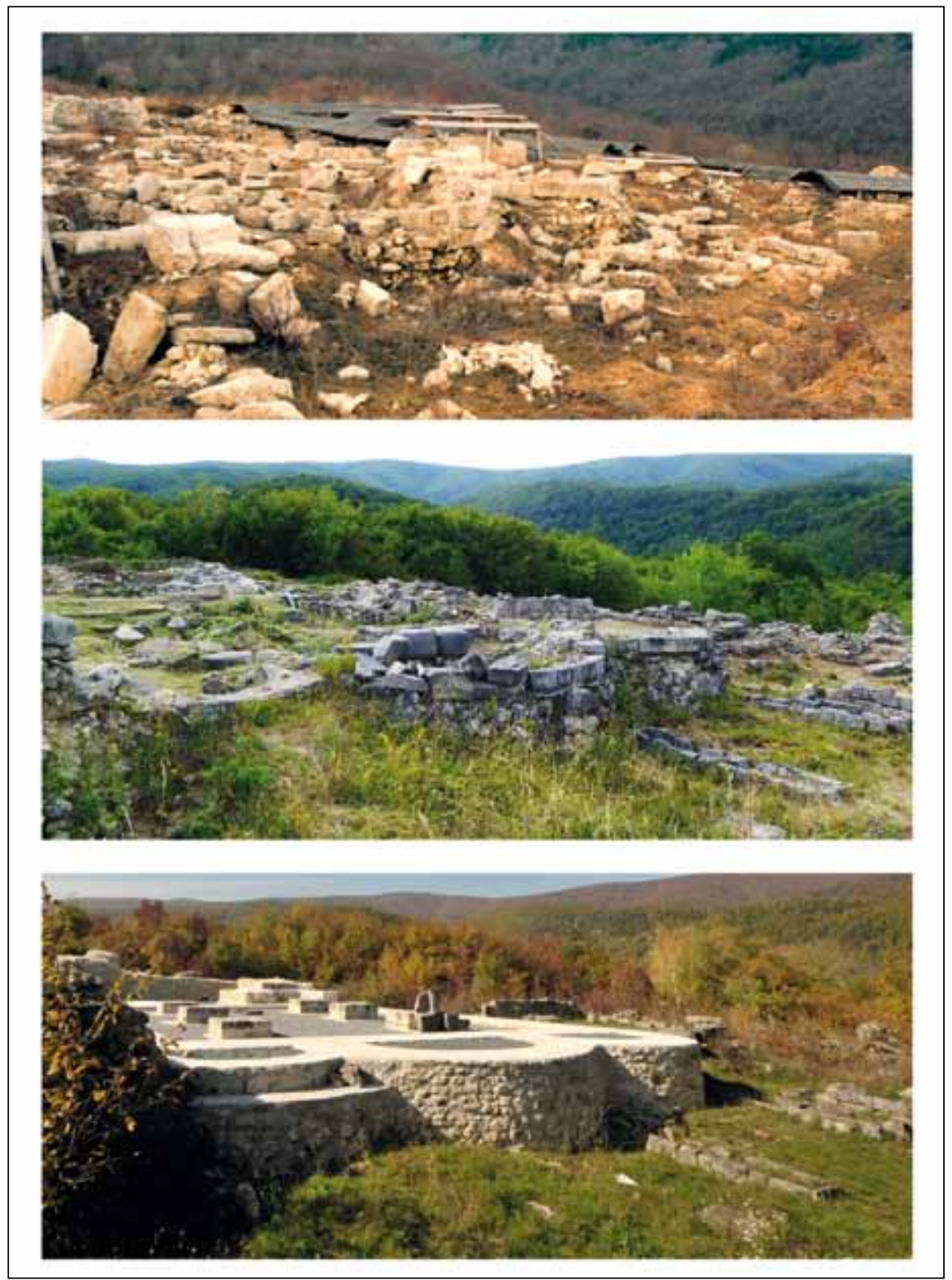

Slika 11. Pogled s jugoistoka na rudinsku opatijsku crkvu prije, tijekom i nakon prve faze konzervatorsko-restauratorskih građevinskih radova. Snimke: GMP, 1992. (arhiva GMP-a) i T. Pleše, 2013. i 2015. (arhiva HRZ-a) 
Radovi Zavoda za znanstveni i umjetnički rad u Požegi, 7 (2018), str. 91-135

T. Pleše; P. Sekulić; B. Mostarčić: Ususret četvrtom desetljeću od početka istraživanja...

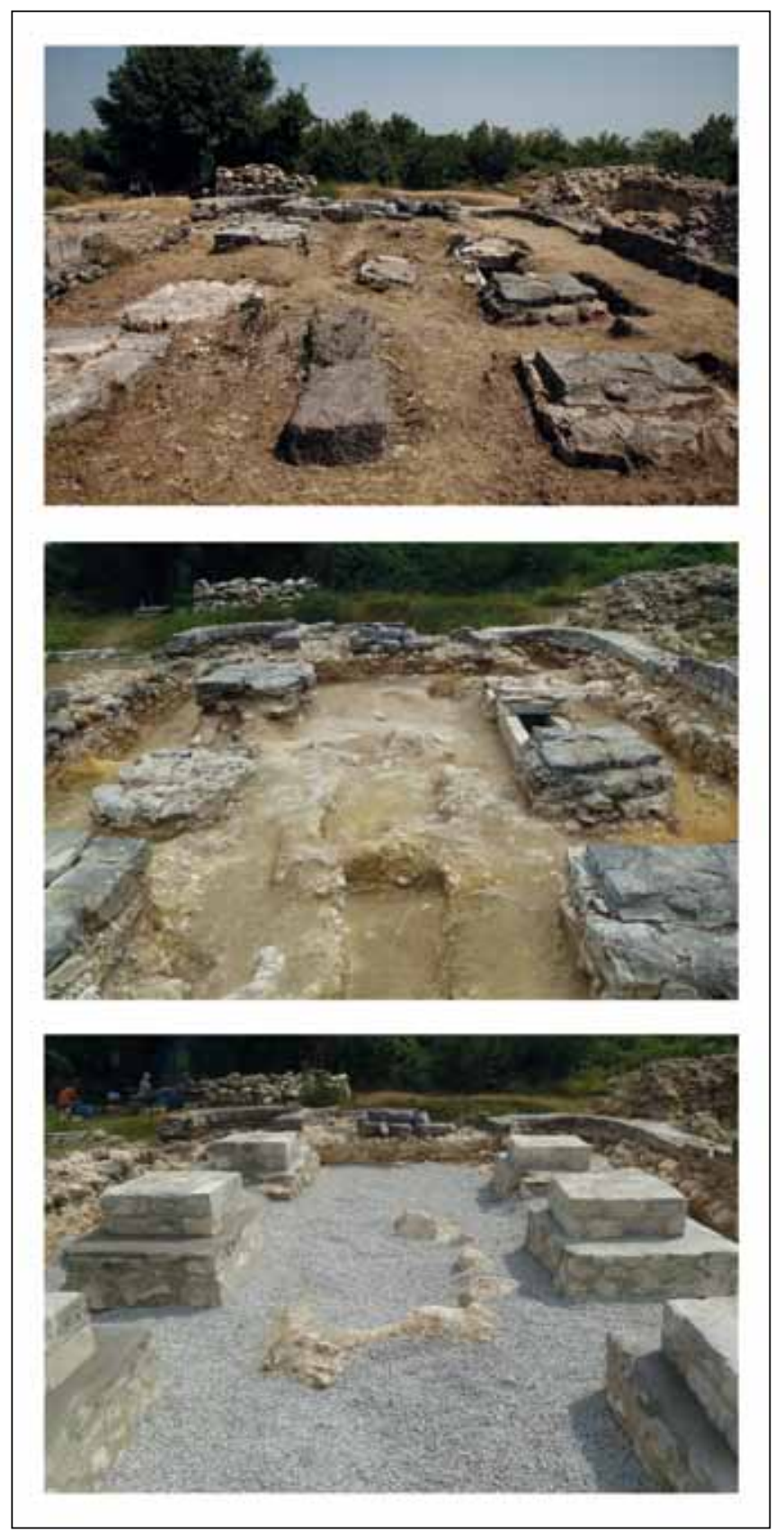

Slika 12. Pogled sa zapada na rudinsku opatijsku crkvu prije i tijekom prve faze konzervatorsko-restauratorskih građevinskih radova. Snimke: T. Pleše, 2013. i 2014. (arhiva HRZ-a) 
Radovi Zavoda za znanstveni i umjetnički rad u Požegi, 7 (2018), str. 91-135

T. Pleše; P. Sekulić; B. Mostarčić: Ususret četvrtom desetljeću od početka istraživanja...

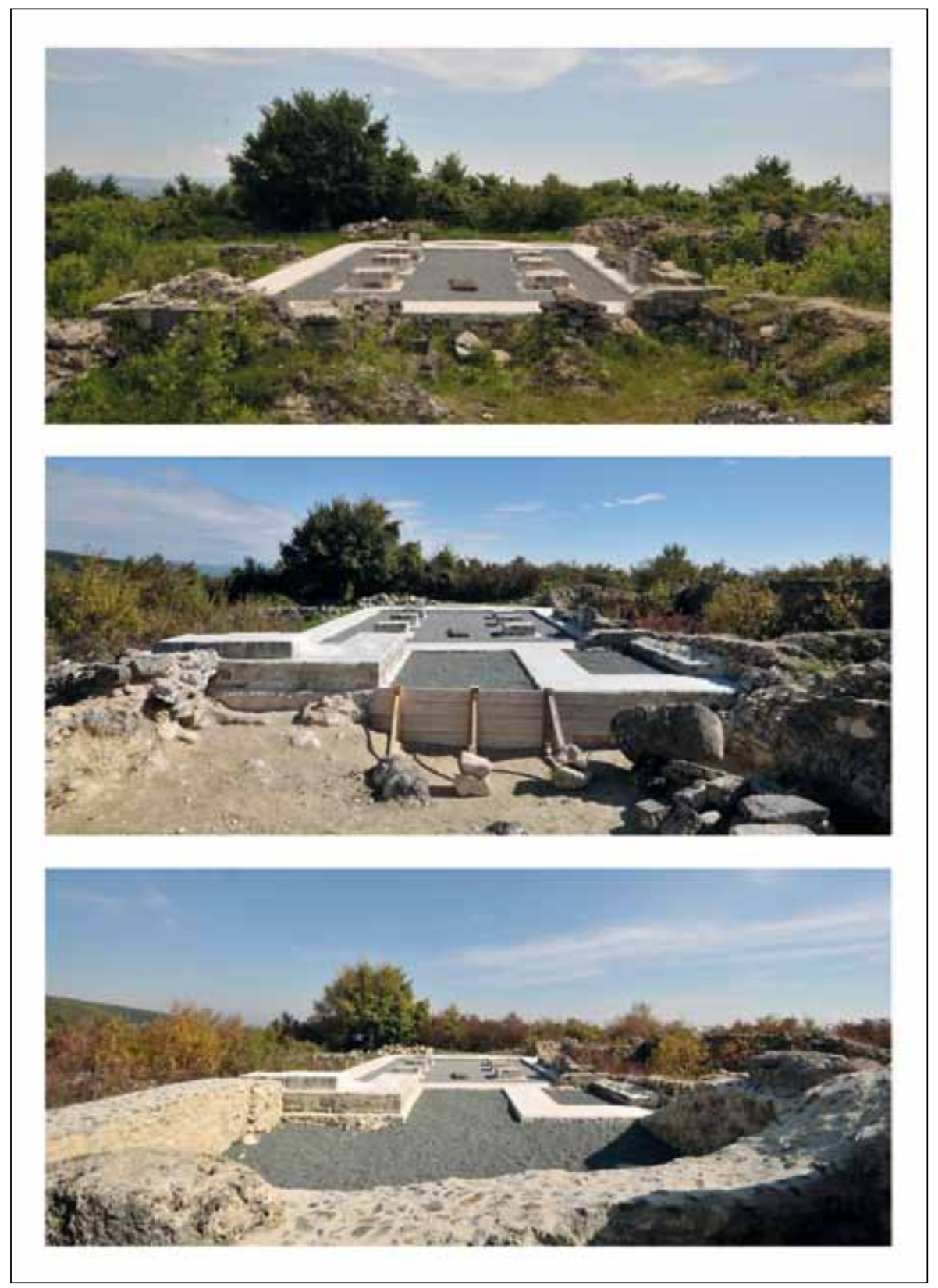

Slika 13. Pogled sa zapada na rudinsku opatijsku crkvu tijekom i nakon prve faze konzervatorsko-restauratorskih građevinskih radova.

Snimke: T. Pleše, 2015., 2016. i 2017. (arhiva HRZ-a) 
Tijekom 2015. godine provedena su i revizijska istraživanja ${ }^{47}$ te građevinski radovi konzerviranja i prezentiranja opatijske grobljanske kapele čija je zidna masa također bila konzervirana cementnim mortom 1982. godine. Nažalost, tijekom ovih radova nije pronađen ni jedan sačuvani trag hodnog sloja. Slika 14 i 15

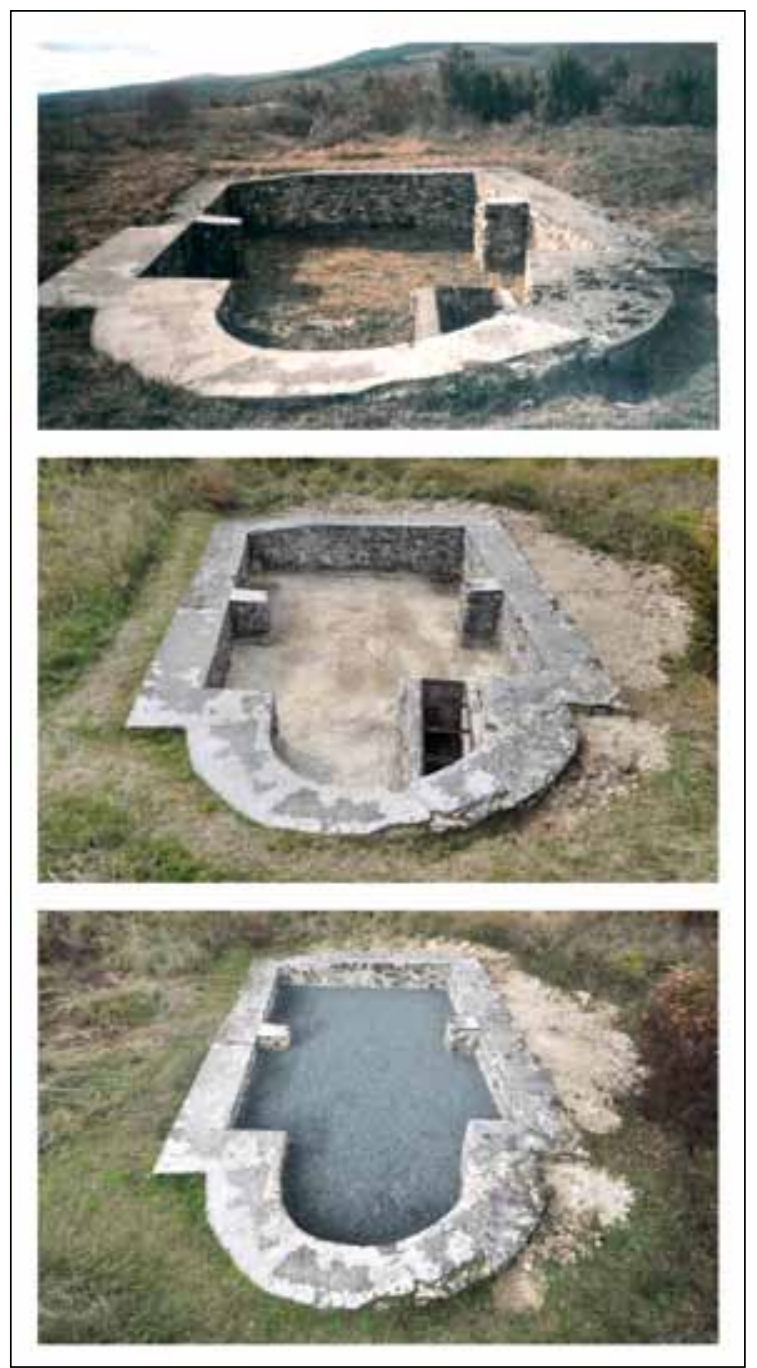

Slika 14. Pogled s istoka na rudinsku grobljansku kapelu prije, tijekom i nakon prve faze konzervatorsko-restauratorskih građevinskih radova. Snimke: GMP, 2004.

(arhiva GMP-a) i T. Pleše, 2015. (arhiva HRZ-a)

\footnotetext{
${ }_{47}$ Osim ljudskog osteološkog materijala te veće količine otpadaka, nisu pronađeni drugi pokretni arheološki nalazi.
} 


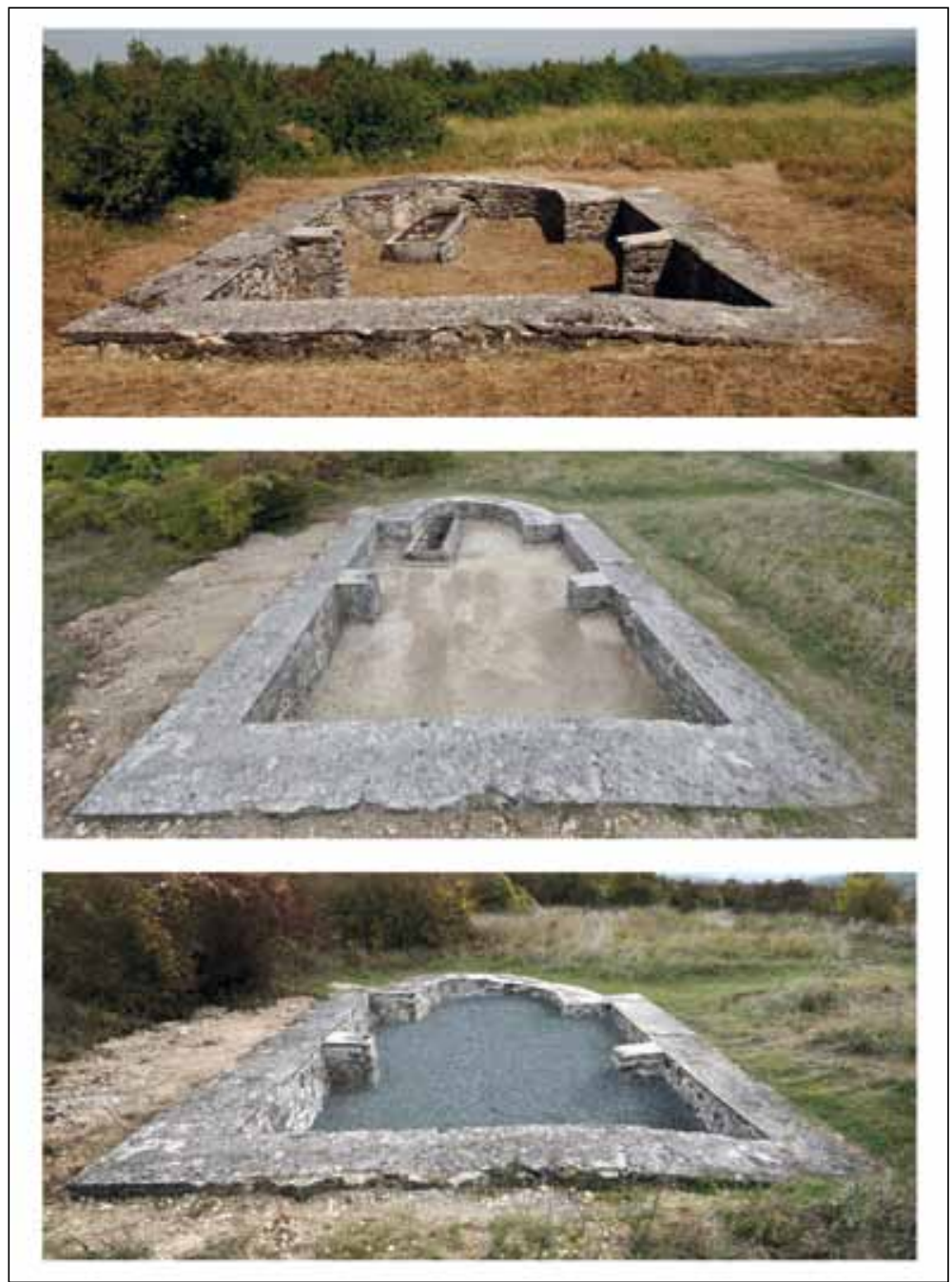

Slika 15. Pogled sa zapada na rudinsku grobljansku kapelu prije, tijekom i nakon prve faze konzervatorsko-restauratorskih građevinskih radova. Snimke: T. Pleše, 2015. (arhiva HRZ-a)

Način neprezentiranja grobnica primijenjen je i na grobnici pronađenoj u kapeli. No s nje nije uklonjena željezna konstrukcija (koja je nosila transparentne ploče), također kao svjedočanstvo starih konzervatorskih rješenja.

$S$ obzirom na to da je cementni mort još uvijek $u$ dobrom stanju, odlučeno je da se do daljnjega neće uklanjati. Nakon dovršetka nužnih popravaka temelja, kapela je zatrpana drobljenim kamenom $(8-11 \mathrm{~mm})$ do visine od $20 \mathrm{~cm}$ niže od gornje kote južnog ramena apside predmetnog objekta. 
Od 2015. do 2017. godine subsekventno s konzervatorsko-restauratorskim radovima na građevinskoj sanaciji s intencijom prezentiranja, revizijski je istražen i prostor predvorja crkve s oba zvonika. Parcijalno je, u skladu s radovima, revidiran i uski prostor uz vanjska pročelja zapadnog i južnog zida toga dijela rudinskog objekta. ${ }^{48}$ S obzirom na temeljita istraživanja koja je 2002. godine proveo IARH, nije bilo novih nalaza $u$ unutrašnjosti zapadne prigradnje uz zapadno pročelje opatijske crkve.

Slike 10 - 13 i 16

\section{Umjesto zaključka}

Sagrađena na psunjskom platou s kojega se pruža pogled na cijelu Požešku dolinu, rudinska je opatija čak i u svojem unutarnjem arhitektonskom ustroju pratila opisnu sintagmu Reda Benedictus amat montes. Opatija je, naime, u cijelosti sagrađena sa zatečenom geomorfologijom terena. Takva je, naoko problematična, dispozicija riješena terasastim ustrojem prostora: opatijska crkva nalazi se na najvišem (i zato najbolje vidljivom) položaju, na srednjem se pak nalazi klaustar, dok se na najnižem, cestom najpristupačnijem dijelu nalazi sjeverno opatijsko krilo. Određivanjem sv. Mihovila arkanđela za titulara opatije, čije je ime birano još od ranog kršćanstva za zaštitnika objekta smještenih na takvim ekspresivnim, vjetru izloženim položajima, zaokruženo je utjelovljenje već spomenute sintagme Benedictus amat montes.

Rudinska je opatija najvjerojatnije građena tijekom 12. stoljeća u jeku romaničkog stilskog oblikovanja, blisko povezanog s reformom crkve (samim tim i liturgije koja se u njoj održavala). Kao što je to sročio M. Jurković: „reforma je iznjedrila pobjedničku crkvu koja se nužno morala iskazati i materijalizacijom novog položaja, iz čega je proistekao osnovni koncept eksteriornosti - iznošenjem skulpture na fasade. Iz toga pak proizlazi nastojanje za uspostavom arhitektonsko-skulptorske tektonske cjeline, što nužno iziskuje strukturalizaciju masa nasuprot ranijem plošnom zidanju" (Jurković, 1996: 327). To je dokazano tzv. rudinskim glavama, jednom od najzanimljivijih cjelina arhitektonske figuralne plastike u Slavoniji, dok se ten-

48 Ujedno je tijekom radova provedenih 2017. revidirana grobnica istražena 1986. godine, koja je bila datirana kao ranokršćanska (Sokač Štimac, 1986a: 17). Na jednoj od poklopnica prikazana je stilizirana riba. Shodno stilskoj analizi, tu je grobnicu D. Sokač Štimac odredila kao ranokršćansku i datirala na prijelaz 3. i 4. stoljeća (Demo / ur./ 1994: 125, kat. br. 177; Sokač Štimac, 1997: 17-18; Sokač Štimac, 2013: 4-5). No u pismohrani GMP-a nađen je dopis od 5. veljače 1988. godine koji je Institut uputio GMP-u. Tekst dopisa donosimo u cijelosti: „Poštovana kolegice Sokač, U vezi Vaše narudžbe dostavljamo Vam rezultat 14C analize kostiju iz groba G-1 s lokaliteta Rudina u Požeškoj kotlini: Starost: 525 +- 120 BP (od 1950. godine). Dendrokronološka korekcija ovako dobivene 14C starosti daje godinu: AD 1400 +120. U nadi da će Vam ovaj rezultat pomoći u rješavanju Vaših problema, dr. Bogomil Obelić."

Pregledom sve dostupne dokumentacije ustanovljeno je da je ulomak rimskog sarkofaga s prikazom stilizirane ribe sekundarno iskorišten pri gradnji grobnice datirane analizom kostiju pokojnika $\mathrm{u}$ 15./16. stoljeće. 
dencija pejzažnoj dojmljivosti ogleda u dva masivna zvonika na zapadnom pročelju opatijske crkve.

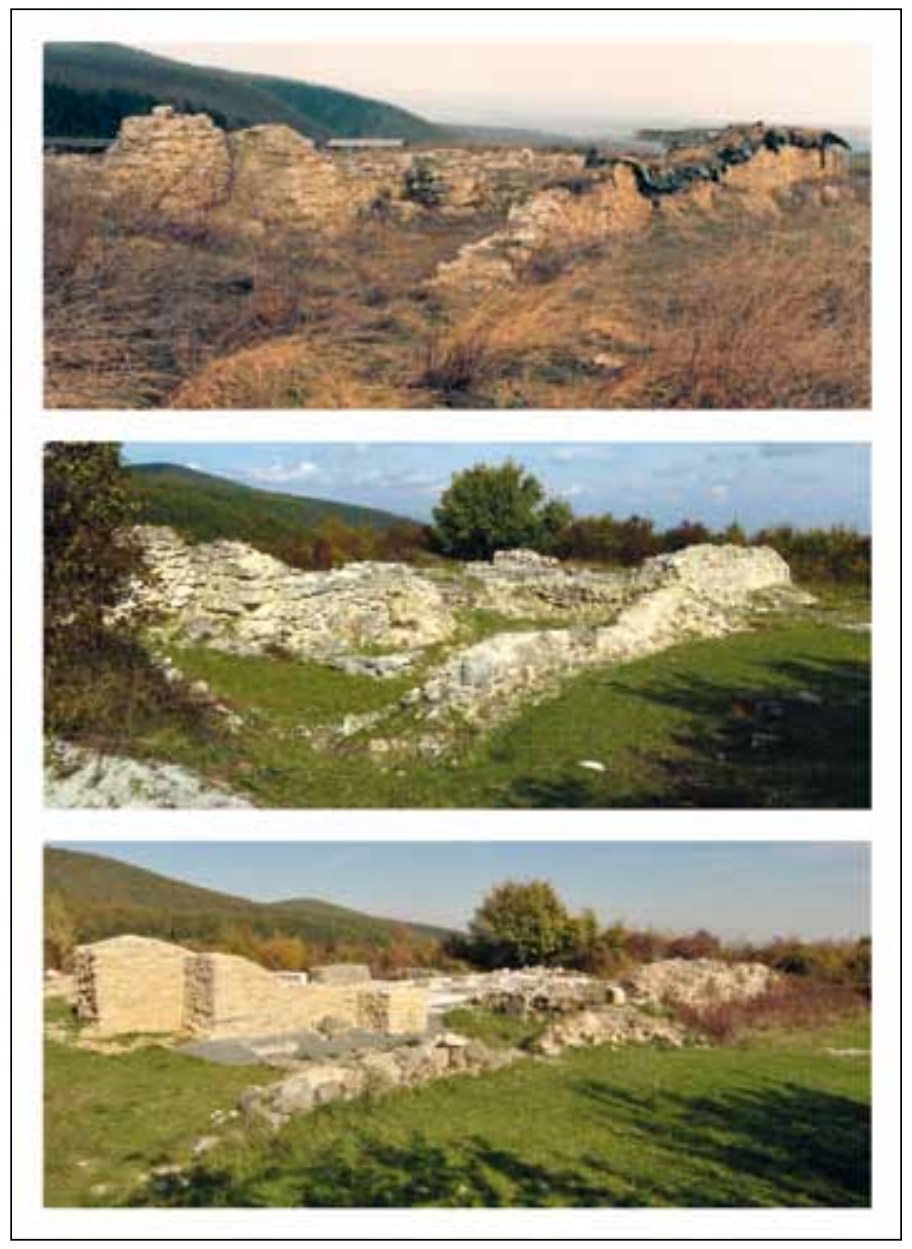

Slika 16. Pogled s jugozapada na rudinsku opatiju prije, tijekom i nakon prve faze konzervatorsko-restauratorskih građevinskih radova. GMP, 1992. (arhiva GMP-a) i T. Pleše, 2013. i 2017. (arhiva HRZ-a)

Unatoč tome što nam za sada nisu poznata sačuvana vrela koja bi potvrdila postojanje benediktinske opatije u Rudini prije 13. stoljeća, opći je zaključak da se njezin osnutak datira u sredinu (Ostojić, 1965), odnosno kraj 12. stoljeća (Horvat, 1962; Geber, 1979; Andrić, 1998; Sekulić Gvozdanović, 2007). Gradnja je zasigurno trajala nekoliko desetljeća, a opatija je neminovno bila pregrađena i/ili dograđena u stoljećima nakon toga. 
Osim vremena osnutka, nepoznanicom je ostao i osnivač opatije. Na temelju poznatih podataka čini se logičnom pretpostavka o pripadnicima roda Borić kao osnivačima opatije (Adamček, 1977; Klaić, 1986; Karbić, 2005). U prilog tome uzima se i smještaj rudinske opatije i njezinih posjeda na području posjeda roda Borića, i to uz njihove nasljedne zemlje, kao i sačuvani podaci o patronima opatije (Karbić, 2005a: 192). Upravo je ban Borić u drugoj polovici 12. stoljeća bio vodeća ličnost na prostoru Požeške županije, odnosno velikaš snažno povezan s kraljevskim dvorom. Svakako je zanimljiva pretpostavka da je opatija mogla biti ukopno mjesto roda, barem u nekom razdoblju, što je prema nekim autorima jedna od odlika rodovskih samostana (Karbić, 2005a: 193). Dok kasnija sačuvana vrela svjedoče o ograničenoj gospodarskoj moći opatije, njezina umjetničko-arhitektonska vrijednost može upućivati na iznimno (političko?) značenje prilikom osnutka, kao i na moć osnivača.

Mnogim nepoznanicama unatoč, sigurno je da je Rudina iznimno važno „monumentalno ostvarenje romaničkog tipa u sjevernim krajevima Hrvatske" (Mohorovičić, 1960: 430-431).

Kao što i pristoji takvom objektu, u prvoj je građevinskoj fazi rudinska opatija sagrađena kao masivni pravokutnik organiziran oko pravokutnog klaustra, s crkvom smještenom u jugoistočnom dijelu sklopa (istražena bruto površina oko $1091 \mathrm{~m}^{2}$ ) te s grobljanskom kapelom (istražena bruto površina oko $49 \mathrm{~m}^{2}$ ) smještenom 40-ak metara u smjeru jugozapada. Tek je tijekom druge građevinske faze (koju za sada nije moguće datirati) opatija proširena prema jugu i zapadu. Je li ta građevinska faza bila uvjetovana obrambenim potrebama (na što upućuju strijelnica, puškarnice i kameni projektili) kraja 14., odnosno početka 15. stoljeća, ostaje jedno od brojnih otvorenih pitanja. Nadalje, nije poznato je li rudinska opatija bila izmijenjena i treći, posljednji put u prvoj polovici 16. stoljeća, na što upućuju nalazi osmanlijskih nišana.

Kao što je rečeno, opatija je u cijelosti sagrađena u skladu s morfologijom terena. Na najvišoj se terasi nalazila trobrodna opatijska crkva zaključena trima apsidama na istoku te određena dvama masivnim zvonicima na zapadu (prosječni $h 418,20$ mnv). Na istoj su terasi smještene sakristija i kapela, a najvjerojatnije i južni dio zapadnog krila. Klaustar i sjeverni dio zapadnog opatijskog krila bili su sagrađeni na nižem platou (prosječni $h 417,60 \mathrm{mnv}$ ). Na najnižoj su se terasi nalazili sjeverni dio istočnog krila te cijelo sjeverno opatijsko krilo (prosječni $h 415,40$ mnv). Pristupna se komunikacija najvjerojatnije nalazila na toj strani platoa te je logično pretpostaviti da se na tom mjestu nalazio i glavni ulaz $u$ rudinsku opatiju. $S$ obzirom na navedene visinske vrijednosti, može se s oprezom zaključiti da je prostorna komunikacija među ta tri dijela opatije bila riješena stubama. Je li postojao kat te nad kojim se dijelovima opatije nalazio, za sada nije moguće zaključiti.

Iako je rudinska opatija jedan od najznačajnijih kasnosrednjovjekovnih sakralnih objekata na prostoru kontinentalne Hrvatske, već ga više od stoljeća prati zla 
kob koja je počela ekstenzivnim odvozom kamene građe u vrijeme M. Rajnera, a nastavila se arheološkim istraživanjima koja su u ovom slučaju pokazala proturječan karakter. Naime, iako su istraživanja bila potrebna za proučavanje, razumijevanje i dokumentiranje svakog nalazišta, na rudinskom je primjeru jasno iskazan i njihov destruktivni karakter. Sukus problema sažeo je Ž. Španiček, zaključivši da je propadanje rudinske opatije rezultat nedostatnih sredstava za zaštitne radove, nepostojanja jasne koncepcije obnove i prezentacije te parcijalnih i neadekvatnih pokušaja konzerviranja (Španiček, 2013: 168-170).

U nastojanju da se ublaži alarmantno stanje rudinske opatije, provedena su 2013. godine revizijska istraživanja s ciljem izrade cjelovite nacrtne dokumentacije te izrade tehničkog opisa objekta. Uslijedila su revizijska istraživanja cijele crkve i predvorja, a provedeni su i prvi koraci u njezinu trajnom konzerviranju.

U skladu s financijskim mogućnostima, nastavit će se građevinski radovi na konzerviranju i rekonstrukciji rudinske opatije da bi se adekvatno prezentirao taj iznimni spomenik kasnosrednjovjekovne nepokretne sakralne kulturne baštine.

\section{Popis literature}

Adamček, Josip (1977), Požega i Požeška županija u srednjem vijeku. U: M. Strbašić (ur.), Požega 1227-1977. Slavonska Požega: Skupština općine Slavonska Požega Odbor za proslavu 750. godišnjice grada Slavonske Požege, str. 111-120.

Andrić, Stanko (1998), Benediktinski samostan sv. Mihovila Arkanđela na Rudini. Zlatna dolina: godišnjak Požeštine, 4, str. 31-57.

Andrić, Stanko (2003), Prilog srednjovjekovnoj topografiji i hidrografiji Psunjskopapučkog kraja. Scrinia Slavonica, 3, str. 70-94.

Andrić, Stanko (2005), Benediktinska opatija svete Margarete u Grabovu i njezin odnos prema benediktinskom samostanu u Bijeli. Scrinia Slavonica, 5, str. 62-98.

Andrić, Stanko (2008), Podgorje Papuka i Krndije u srednjem vijeku: prilozi za lokalnu povijest (prvi dio). Scrinia Slavonica, 8, str. 55-112.

Andrić, Stanko (2009), Podgorje Papuka i Krndije u srednjem vijeku: prilozi za lokalnu povijest (drugi dio). Scrinia Slavonica, 9, str. 57-98.

Andrić, Stanko (2010), Podgorje Papuka i Krndije u srednjem vijeku: prilozi za lokalnu povijest (treći dio). Scrinia Slavonica, 10, str. 87-130.

Bösendorfer, Josip (1910), Crtice iz slavonske povijesti s osobitim obzirom na prošlosti županija: križevačke, virovitičke, požeške, visdravske baranjske, vukovarske i srijemske te kr. i slob. Grada Osijeka u srednjem i novom vijeku. Osijek: Tiskom knjigo i kamenotiskare Julija Feiffera. 
Buturac, Josip (1934), Župe požeškog arhiđakonata g. 1332.-1335. Bogoslovska smotra, 22, str. 81-90.

Buturac, Josip (2004), Pisani spomenici Požege i okolice 1210.-1536. Jastrebarsko: Biblioteka Posegana, Naklada Slap.

Buzás, Gergely (2012), The 16th century reconstruction and vault of the church of the Benedictine abbey at Somogyvár. http://www.hungarianarchaeology.hu/wp-content/ uploads/2012/11/

Ćuk, Juraj (1925), Požeško plemstvo i požeška županija u doba prvih sačuvanih imena i naziva do polovice četrnaestog vijeka. Rad JAZU, 229, str. 38-101.

Gabór, Gabriella (2006), Középkori pártaövek Békés megyében / „Parta“-belts (ornamented belts) in Békés county from the Middle Ages. A Békés Magyei Múzeumok Közleményei, 28, str. 111-130.

Geber, Eleonora (1975), Historijat Muzeja Požeške kotline. Muzeologija, 19, str. 1-7.

Geber, Eleonora (1979), Sačuvani ostaci benediktinske opatije Rudina u Muzeju Požeške kotline. Vjesnik Muzeja Požeške kotline, 2-3, str. 105-129.

Le Goff, Jacques (1974), Srednjovjekovna civilizacija zapadne Europe. Jugoslavija, Beograd.

Grgin, Hrvoje (2012), Plemićki rod Deževića Cerničkih u kasnome srednjem vijeku. U: D. Jelčić et al. (ur.), Radovi s okruglog stola Rudina - prošlost u budućnosti. Požega: Zavod za znanstveni i umjetnički rad HAZU Požega, str. 107-130.

Heller, Georg (1975), Comitatus Poseganensis. München: Veröffentichungen des Finnisch-Ungarischen Seminars an der Universität Munchen, Band 3.

Horvat, Anđela (1962), Rudine u Požeškoj kotlini - ključni problem romanike u Slavoniji. Peristil, 5, str. 11-28.

Ivančević Španiček, Lidija (1997), Rudina - biser romanike u Slavoniji. U: D. Sokač Štimac (ur.), Rudina: benediktinska opatija Sv. Mihovila. Požega: Gradski muzej Požega, str. 25-30.

Janeš, Andrej i Sekulić, Petar (2014), Rudina i Bijela - benediktinski samostani kasnosrednjovjekovne Slavonije. Starohrvatska prosvjeta, 41, str. 185-204.

B. Jungklaus, Bettina (2013), Soziale Gliederung der spätmittelalterlichen Stadtbevölkerung im Spiegel der Bestattungsplätze und anthropologischer Untersuchungen. Die Deutsche Gesellschaft für Archäologie des Mittelalters und Neuzeit, 25, str. 105-116.

Jurković, Miljenko (1996), Pojava romaničke arhitekture u Hrvatskoj. U: M. Jurković, T. Lukšić (ur.), Starohrvatska spomenička baština - radanje proog hrvatskog kulturnog pejzaža. Zbornik radova znanstvenog skupa održanog 6.-8. listopada 1992. godine. Zagreb: Exegi monumentum - znanstvena izdanja 3, str. 325-338. 
Karbić, Marija (2003), Plemićki rodovi njemačkog podrijetla u Požeškoj županiji tijekom srednjeg vijeka. Godišnjak Njemačke narodnosne zajednice, 10, str. 67-76.

Karbić, Marija (2005), Rod Borića bana, primjer plemićkog roda u srednjovjekounoj Požeškoj županiji. Zagreb: doktorska disertacija.

Karbić, Marija (2005a), Posjedi plemićkog roda Borića bana do sredine XIV. stoljeća. Scrinia Slavonica, 5, str. 48-61.

Kempf, Julije (1907), Posljednji ostaci srednjovječne opatije Rudine. Vjesnik Arheološkog muzeja u Zagrebu, 9, str. 245-246.

Kempf, Julije (1910), Požega: zemljopisne bilješke iz okoline i prilozi za povijest slobodnog kraljevskog grada Požege i Požeške kotline. Požega: Štamparija „Hrvatske tiskare i knjižare", str. 115-116.

Kiss, Gergely Bálint (2009), Utemeljenje i teritorijalni opseg Pečuške biskupije. Scrinia Slavonica, 9, str. 351-378.

Klaić, Nada (1986), Ecclesia seu monasterium sancti Michaelis de Rudina. Vjesnik Muzeja Požeške kotline, 4-5, str. 33-59.

Kramberger, Vjekoslav (2013), Bula pape Bonifacija IX. pronađena na Rudini. U: D. Jelčić et al. (ur.), Radovi s okruglog stola Rudina - prošlost u budućnosti. Požega: Zavod za znanstveni i umjetnički rad HAZU Požega, str. 103-113.

Krznar, Siniša (2012), Arheološka slika kasnosrednjovjekovnih groblja na prostoru sjeverne Hroatske. Zagreb: doktorski rad, Sveučilište u Zagrebu.

Levente Szocs, Peter (2016), Archaeological Evidences of Monastic Patronage: Several Case Studies. U: I. M. Ţiplic i M. Crîngaci Tुiplic (ur.), ArhIn I. Medieval Changing Landscape. Settlements, Monasteries and Fortifications. Sibiu: Editura „ASTRA Museum", str. 171-187.

Lukinović, Andrija (2004), Povijesni spomenici zagrebačke biskupije. Svezak VII. (1441.1465.). Zagreb: Croatica Christina Fontes.

Margetić, Dalibor i Margetić, Davor (2005), Pečat pape Eugena IV. s Rudine. Numizmatičke vijesti, 58, str. 290-292.

Matijević, Marijana (2013), Gotičke keramičke čaše iz Rudine. U: D. Jelčić et al. (ur.), Radovi s okruglog stola Rudina - prošlost u budućnosti. Požega: Zavod za znanstveni i umjetnički rad HAZU Požega, str. 61-86.

Mažuran, Ive (1977), Požega i Požeška kotlina za turske vladavine. U: M. Strbašić (ur.), Požega 1227-1977. Slavonska Požega: Skupština općine Slavonska Požega Odbor za proslavu 750. godišnjice grada Slavonske Požege, str. 161-198.

Moačanin, Nenad (1997), Požega i Požeština u sklopu Osmanlijskog carstva (1537.-1691.). Jastrebarsko: Biblioteka Posegana, Naklada Slap. 
Moačanin, Nenad (1984), Granice i upravna podjela Požeškog sandžaka. Zbornik Odsjeka za povijesne znanosti Zavoda za povijesne i društvene znanosti HAZU, 13, str. 107-118.

Mohorovičić, Andrija (1960), Problem razvoja romaničke arhitekture na tlu Hrvatske razmatran s osvrtom na ruševni kompleks Rudina u Slavoniji. Ljetopis JAZU, 64, str. 417-431.

Mujadžević, Dino (2009), Osmanska osvajanja u Slavoniji 1552. u svjetlu osmanskih arhivskih izvora. Povijesni prilozi, 36, str. 89-108.

Mujadžević, Dino (2010), Pregled osmanskih arhivskih izvora za povijest Slavonije i Srijema. Scrinia Slavonica, 10, str. 131-142.

Novak, Mario (2013), Antropološka analiza ljudskih koštanih ostataka s nalazišta Rudina - benediktinski samostan sv. Mihovila. U: D. Jelčić et al. (ur.), Radovi s okruglog stola Rudina -prošlost u budućnosti. Požega: Zavod za znanstveni i umjetnički rad HAZU Požega, str. 115-136.

Ostojić, Ivan (1965), Benediktinci u Hrvatskoj i ostalim našim krajevima. Svezak III. Split: Benediktinski priorat Tkon.

Pavličić, Mirela (2012), Prikaz srednjovjekovnih pećnjaka s lokaliteta benediktinske opatije Sv. Mihovila u Rudini. Radovi Zavoda za znanstveni i umjetnički rad HAZU Požega, 1, str. 231-246.

Pleše, Tajana i Sekulić, Petar (2014), Rudina - benediktinska opatija sv. Mihovila arkandela. Izvještaj o revizijskim istraživanjima provedenim tijekom 2013. godine. Zagreb: pismohrana HRZ-a.

Pleše, Tajana i Sekulić, Petar (2014), Čečavac - Rudina, benediktinska opatija sv. Mihovila arkanđela. Elaborat o revizijskim istraživanjima opatijske crkve provedenim tijekom 2014. godine (svezak 1 i 2). Zagreb: pismohrana HRZ-a.

Rupert, Kristina (2013), Topografija Požeške županije do 1526. godine. Zagreb: diplomski rad.

Rusu, Adrian Andrei i Burnichioiu, Ileana (2011), Mănăstirea Bizere I. Cluj - Napoca: Editura Mega.

Sekelj Ivančan, Tajana (1997), Kasnosrednjovjekovne keramičke čaše iz Sokolovca, Rudine -Čečavca i Kapan - Ivanca. Prilozi Instituta za arheologiju, 13-14, str. 161-171.

Sekulić Gvozdanović, Srebrenka (2007), Utvrdeni samostani na tlu Hrvatske. Zagreb: Golden marketing - Tehnička knjiga - Arhitektonski fakultet Sveučilišta u Zagrebu.

Sokač Štimac, Dubravka (1980), Dneunik arheoloških iskapanja na benediktinskom lokalitetu Rudina kod Čečavca. Požega: pismohrana GMP-a. 
Sokač Štimac, Dubravka (1984), Prilog arheološkoj topografiji Požeške kotline u svjetlu iskopavanja 1980. godine. Arheološka istraživanja u istočnoj Slavoniji i Baranji. Zagreb: Izdanja Hrvatskog arheološkog društva, str. 140-141.

Sokač Štimac, Dubravka (1986a), Dnevnik arheoloških iskapanja na Rudini 1986. godine. Požega: pismohrana GMP-a.

Sokač Štimac, Dubravka (1986b), Izvještaj o arheološkim iskapanjima na srednjovjekovnom lokalitetu Rudina kod Slavonske Požege. Požega: pismohrana GMP-a.

Sokač Štimac, Dubravka (1986c), Prvi rezultati arheoloških iskapanja u Rudini u Požeškoj kotlini. Vjesnik Muzeja Požeške kotline, 4-5, str. 5-32.

Sokač Štimac, Dubravka (1987a), Dneonik arheoloških iskapanja na srednjovjekovnom lokalitetu Rudina. Požega: pismohrana GMP-a.

Sokač Štimac, Dubravka (1987b), Izvještaj o arheološkim iskapanjima na srednjovjekovnom lokalitetu Rudina kod Slav. Požege. Požega: pismohrana GMP-a.

Sokač Štimac, Dubravka (1987c), Rudina kod Slavonske Požege, romanička crkva i samostan. Požega: pismohrana GMP-a.

Sokač Štimac, Dubravka (1988a), Dneonik sistematskih arheoloških iskapanja na Rudini 1988. godine. Požega: pismohrana GMP-a.

Sokač Štimac, Dubravka (1988b), Izvještaj o nastavku sistematskih arheoloških iskapanja na srednjovjekovnom lokalitetu Rudina. Požega: pismohrana GMP-a.

Sokač Štimac, Dubravka (1988c), Probna arheološka iskapanja u Kujniku 1988. godine. Požega: pismohrana GMP-a.

Sokač Štimac, Dubravka (1989a), Dneonik arheoloških iskapanja na srednjovjekovnom lokalitetu Rudina u Požeškoj kotlini. Požega: pismohrana GMP-a.

Sokač Štimac, Dubravka (1989b), Izvještaj o nastavku sistematskih arheoloških iskapanja na srednjovjekovnom lokalitetu Rudina u Požeškoj kotlini. Požega: pismohrana GMP-a.

Sokač Štimac, Dubravka (1989c), Rudina kod Slavonske Požege, romanička crkva i samostan. Arheološki pregled 1987., str. 175-177.

Sokač Štimac, Dubravka (2000a), Dnevnik arheoloških istraživanja na srednjovjekovnom nalazištu Rudina. Požega: pismohrana GMP-a.

Sokač Štimac, Dubravka (2000b), Izvješće o arheološkim istraživanjima na Rudini. Požega: pismohrana Konzervatorskog odjela u Požegi.

Sokač Štimac, Dubravka (1997), Arheološka istraživanja na Rudini. U: D. Sokač Štimac (ur.), Rudina: benediktinska opatija sv. Mihovila. Požega: Gradski muzej Požega, str. 17-24.

Sokač Štimac, Dubravka (2006), Rudina - benediktinska opatija sv. Mihovila. U: A. Durman (ur.), Stotinu hrvatskih arheoloških nalazišta. Zagreb: Leksikografski zavod Miroslav Krleža. 
Sokač Štimac, Dubravka (2013), Prva sustavna arheološka istraživanja u Rudini. U: D. Jelčić et al. (ur.), Radovi s okruglog stola Rudina - prošlost u budućnosti. Požega: Zavod za znanstveni i umjetnički rad HAZU Požega, str. 1-27.

Sršan, Stjepan, Hafizović, Fazileta i Mažuran, Ive (2001), Popis Sandžaka Požega 1579. godine. Osijek: Državni arhiv u Osijeku.

Szabo, Gjuro (1907), Tri benediktinske opatije u županiji požeškoj. Vjesnik Arheološkog muzeja u Zagrebu, 9, Zagreb, 1907, 201-209.

Szabo, Gjuro (1909), Lijesnica: Historijsko-geografska studija. Vjesnik Hrvatskog arheološkog društva 10, str. 40-48.

Szabo, Gjuro (2006), Sredovječni gradovi u Hrvatskoj i Slavoniji. Zagreb: Golden marketing - Tehnička knjiga.

Šlaus, Mario (2002), Rezultati antropološke analize ljudskog osteološkog materijala s nalazišta Rudina - benediktinski samostan (EP- 63-11/02). Zagreb: stručni izvještaj Odsjeka za arheologiju, HAZU.

Vučić Šneperger, Boris (2013), Samostan sv. Mihovila, Rudina - budućnost povijesnoga graditeljstva. U: D. Jelčić et al. (ur.), Radovi s okruglog stola Rudina - prošlost u budućnosti. Požega: Zavod za znanstveni i umjetnički rad HAZU Požega, str. 137-161.

Španiček, Žarko (2013), Rudina: Arheološka baština kao konzervatorski problem. U: D. Jelčić et al. (ur.), Radovi s okruglog stola Rudina - prošlost u budućnosti. Požega: Zavod za znanstveni i umjetnički rad HAZU Požega, str. 163-174.

Tomičić, Željko, Tkalčec, Tatjana i Ložnjak, Daria (2002), Izvješće o arheološkom istraživanju nalazišta Rudina kraj Čečavca (19. - 23. rujna 2002.). Zagreb: pismohrana Instituta za arheologiju.

Tomičić, Željko, Tkalčec, Tatjana i Ložnjak, Daria (2003), Izvješće o arheološkom istraživanju nalazišta Rudina kraj Čečavca (17. - 24. lipnja 2003.). Zagreb: pismohrana Instituta za arheologiju.

Tomičić, Željko (2013), Novije arheološke spoznaje o Rudini. U: D. Jelčić et al. (ur.), Radovi s okruglog stola Rudina - prošlost u budućnosti. Požega: Zavod za znanstveni i umjetnički rad HAZU Požega, str. 27-61.

Tomičić, Željko (2010), O kasnosrednjovjekovnim knjigama iz benediktinskog samostana sv. Mihovila Arkanđela na Rudini kod Požege. Vjesnik Arheološkog muzeja u Zagrebu, 43, str. 489-501.

Ural, Selçuk (2011), Pakrački sandžak u drugoj polovici 16. stoljeća. Scrinia Slavonica, 11 , str. $61-78$ 


\section{The Benedictine Abbey of St. Michael the Archangel in Rudina - Towards the Fourth Decade Since the Beginning of Research}

\section{Summary}

The Benedictine Abbey of St. Michael the Archangel in Rudina is located on the slopes of the Psunj mountain, near the Čečavac village, on a plateau overlooking the Požega Valley.

Although the Abbey was first mentioned in a document by King Bela IV of 1250, it may be assumed that it was founded by members of the Borić Family in the second half of the $12^{\text {th }}$ century, at the height of the Romanesque style. It was abandoned during the second quarter of the $16^{\text {th }}$ century, just before the establishment of Požega Sanjak.

Despite being a monumental achievement of the Romanesque style in northern Croatia (A. Mohorovičić), the Abbey was marked by centennial misfortune, starting with the extensive removal of stone material during M. Rajner's time. Even though research is necessary to document, study, and understand every site, Rudina Abbey is a testament to M. Wheeler's presumption that all excavation is destruction. This was facilitated by the lack of a clear concept of presentation, as well as by insufficient and inadequate conservation.

Due to the alarming state of the Abbey, revision began in 2013, aiming to develop necessary steps for the conservation and adequate presentation of this exceptional monument of late-medieval cultural heritage.

Keywords: Rudina; Benedictine Abbey; conservation; presentation.

Dr. sc. Tajana Pleše

Hrvatski restauratorski zavod

Nike Grškovića 23, 10000 Zagreb

tplese@h-r-z.hr

Petar Sekulić, prof. povijesti i dipl. arheolog

Odjel za kopnenu arheologiju

Kožarska 5, 10000 Zagreb

psekulic@h-r-z.hr

Boris Mostarčić, dipl. ing. arh.

Hrvatski restauratorski zavod

Nike Grškovića 23, 10000 Zagreb

bmostarcic@h-r-z.hr 
